\title{
MICROCIRCUITRY OF BIPOLAR CELLS IN CAT RETINA ${ }^{1}$
}

\author{
BARBARA A. MCGUIRE, ${ }^{2}$ JOHN K. STEVENS ${ }^{3}$ AND PETER STERLING \\ Department of Anatomy, School of Medicine, University of Pennsylvania, Philadelphia, Pennsylvania 19104
}

Received October 31, 1983; Revised June 4, 1984; Accepted June 6, 1984

\begin{abstract}
We have studied 15 bipolar neurons from a small patch $(14 \times 120 \mu \mathrm{m})$ of adult cat retina located within the area centralis. From electron micrographs of 189 serial ultrathin sections, the axon of each bipolar cell was substantially reconstructed with its synaptic inputs and outputs by means of a computer-controlled reconstruction system. Based on differences in stratification, cytology, and synaptic connections, we identified eight different cell types among the group of 15 neurons: one type of rod bipolar and seven types of cone bipolar neurons. These types correspond to those identified by the Golgi method and by intracellular recording. Those bipolar cell types for which we reconstructed three or four examples were extremely regular in form, size, and cytology, and also in the quantitative details of their synaptic connections. They appeared quite as specific in these respects as invertebrate "identified" neurons.

The synaptic patterns observed for each type of bipolar neuron were complex but may be summarized as follows: the rod bipolar axon ended in sublamina $b$ of the inner plexiform layer and provided major input to the AII amacrine cell. The axons of three types of cone bipolar cells also terminated in sublamina $b$ and provided contacts to dendrites of on- $\beta$ and other ganglion cells. All three types, but especially the $\mathrm{CBb}_{1}$, received gap junction contacts from the AII amacrine cell. Axons of four types of cone bipolar cells terminated in sublamina a of the inner plexiform layer and contacted dendrites of off- $\beta$ and other ganglion cells. One of these cone bipolar cell types, $\mathrm{CBa}_{1}$, made reciprocal chemical contacts with the lobular appendage of the AII amacrine cell.

These results show that the pattern of cone bipolar cell input to $\beta(\mathrm{X})$ and probably $\alpha(\mathrm{Y})$ ganglion cells is substantially more complex than had been suspected. At least two types of cone bipolar contribute to each type of ganglion cell where only a single type had been anticipated. In addition, many of the cone bipolar cell pathways in the inner plexiform layer are available to the rod system, since at least four types of cone bipolar receive electrical or chemical inputs from the AII amacrine cell. This may help to explain why, in a retina where rods far outnumber the cones, there should be so many types of cone bipolar cells.
\end{abstract}

Bipolar cells are the only retinal neurons directly interposed between photoreceptors and ganglion cells. Therefore, knowledge of their connections is likely to be one key to understanding the basis for the receptive field properties of retinal ganglion cells. Until recently, it was thought that bipolar cell anatomy and physiology in the cat retina were relatively simple, because only three kinds of cone bipolar cells were known. Boycott and Kolb (1973) had observed one morphological variety of cone bipolar with dendrites invaginating the cone pedicle and an

${ }^{1}$ This work was supported by National Institutes of Health Grants EY01832, EY00828, EY01583, and Research Career Development Award EY00080 (to P. S.). During part of this work, J. K. S. was supported by a Canadian Medical Research Council grant. We thank Neil Friedman and Robert G. Smith for their computer assistance, Fred Letterio, Ed Shalna, and Alfred M. Reingold for technical support, Donna Heaney, John Megill, and Debby Netsky for technical help, and Susan Heumiller for help with the illustrations. Thanks also to Michael Freed and Dr. James Hamos for useful discussions.

${ }^{2}$ To whom correspondence should be sent, at her present address: The Rockefeller University, 1230 York Avenue, New York, NY 10021.

${ }^{3}$ Present address: Department of Physiology, Playfair Memorial Neuroscience Unit, Toronto Western Hospital, 399 Bathurst Street, Toronto, Ontario M5T 2S8 Canada. axon branching in sublamina $b$ of the inner plexiform layer. They observed two other morphological forms of cone bipolar with dendriles in "flat" contact with the basal surface of the cone pedicle and an axon, either "smooth" or "varicose," branching in sublamina a. The physiological interpretation at the time was correspondingly simple: the invaginating cone bipolar was thought to depolarize at light on and excite the oncenter ganglion cells, and the flat cone bipolars were thought to hyperpolarize at light on and to excite (at light off) the offganglion cells (Famiglietti and Kolb, 1976; Nelson et al., 1978).

Several lines of evidence now suggest that the situation is more complicated. In most species, there are many different kinds of bipolar cell (e.g., Kaneko, 1970; Ramón y Cajal, 1972; Witkovsky and Stell, 1973; West, 1978). In the cat, in particular, there seem to be at least eight morphological forms of cone bipolar neuron based on studies of Golgi-impregnated retinas (Famiglietti, 1981; Kolb et al., 1981). This diversity suggests that the circuits involving bipolar cells may be more complex. Some bipolar cells have been shown to accumulate glycine (Nakamura et al., 1978; Pourcho, 1980), which is thought to act as an inhibitory transmitter in the retina (Wyatt and Daw, 1976; Miller et al., 1977). In addition, both depolarizing and hyperpolarizing types of cone bipolar cells seem to send axons to a single sublamina of the inner plexiform layer where they 


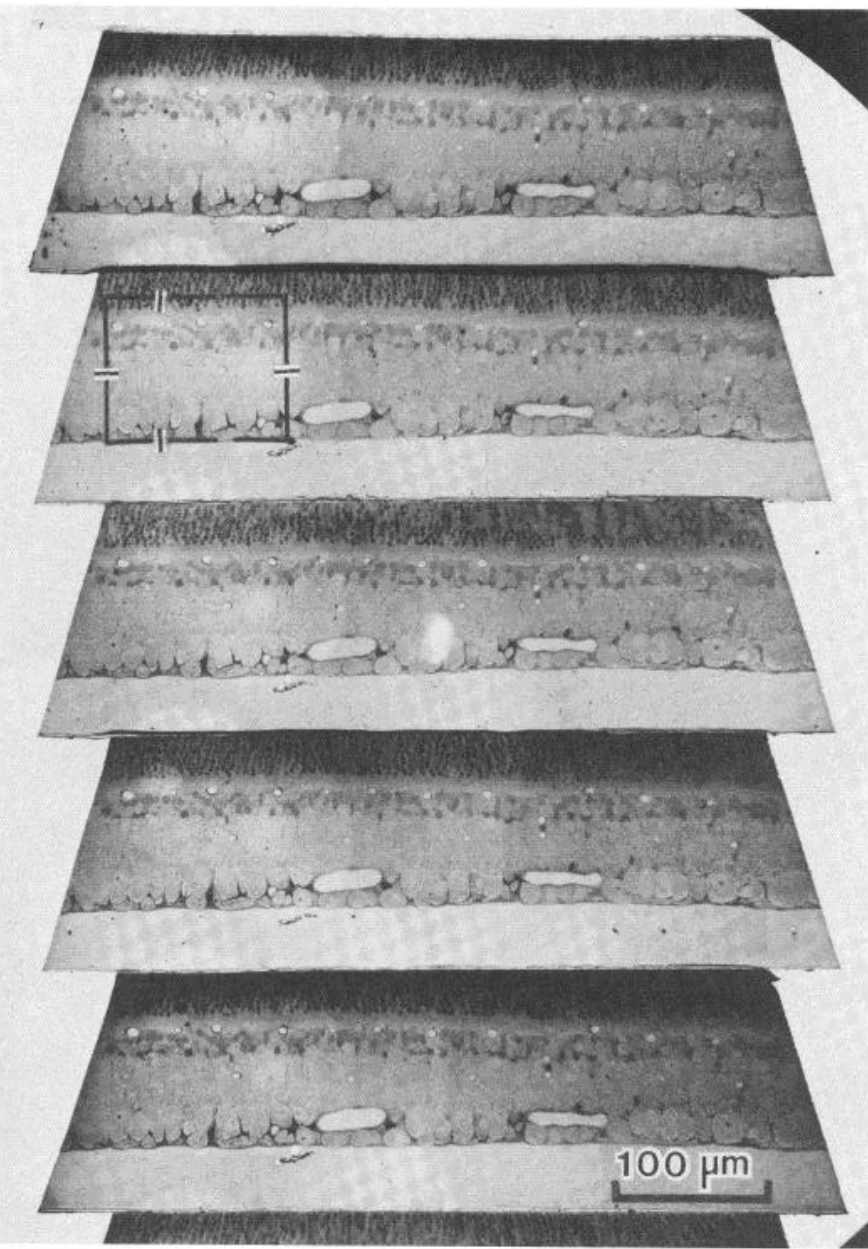

Figure 1. Low magnification electron micrograph of sections 42 to 46. The rectangle in the second section indicates the six regions photographed per section. Ganglion cells formed a solid tier in this region.

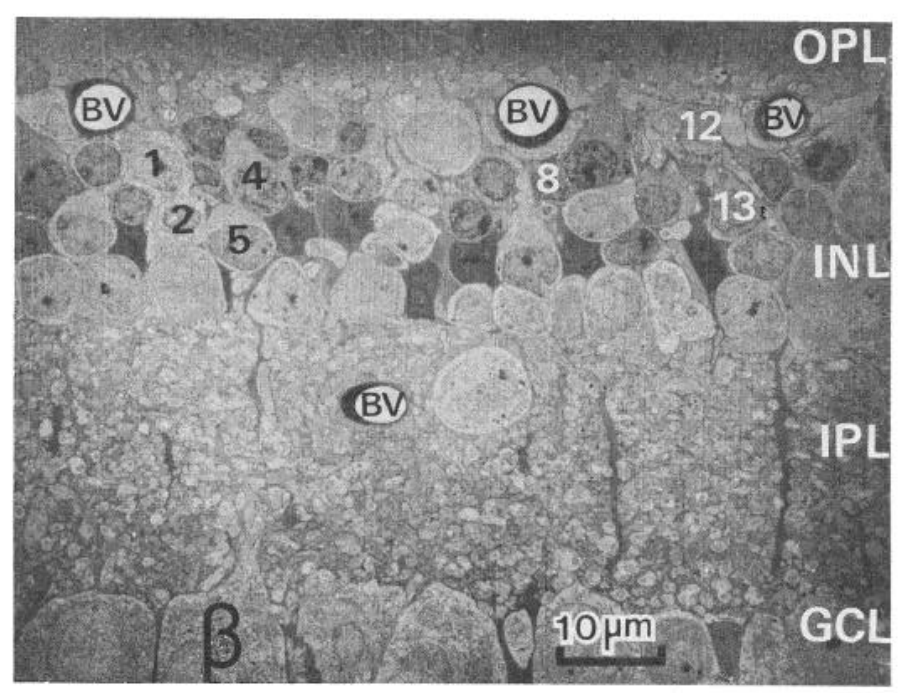

Figure 2. Low magnification electron micrograph of section 59. Numbers mark the somas of seven reconstructed bipolar cells. $\beta$, on- $\beta$ cell; $B V$, blood vessel; $G C L$, ganglion cell layer; $I N L$, inner nuclear layer; $I P L$, inner plexiform layer; $O P L$, outer plexiform layer.

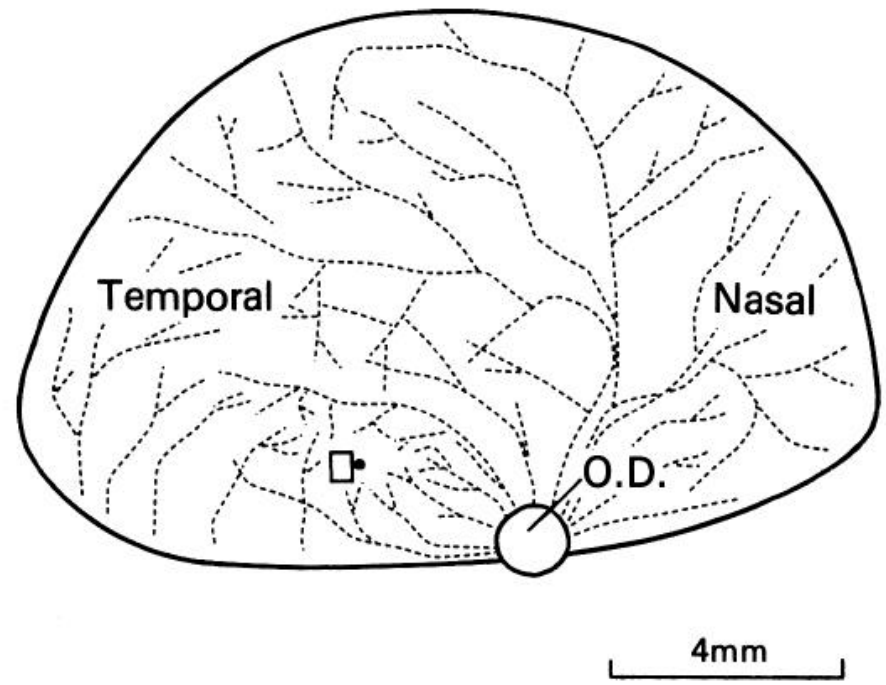

Figure 3. Schematic diagram of right eyecup tapetal area. Tissue for the series was located ( $\square$ ) about $2^{\circ}(0.4$ to $0.5 \mathrm{~mm})$ from the center of the area centralis (๑). O.D., optic disk.

can contact ganglion cells of one type (Kolb and Nelson, 1983; Nelson and Kolb, 1983). In view of these growing complexities, it seemed critical to develop a comprehensive classification of bipolar neurons in which each of the diverse morphological categories could be associated with a distinctive cytology, synaptic circuitry, physiology, and chemistry. If such a classification could be developed, it would then be possible to determine the patterns of contact made by each bipolar cell type with specific types of ganglion cells.

Nelson and Kolb (1983) have approached this problem by recording the responses of bipolar neurons, injecting horseradish peroxidase, and observing the filled cells in the light and electron microscopes. They have established that certain cone bipolar cells have characteristic physiological responses and characteristic synaptic connections. The synaptic patterns were not determined quantitatively, though, for any type. Also, since the method requires accumulating cells at different eccentricities and from different retinas, it is unknown how regular the features of a particular type might be and whether all types are present at every point in the retina.

We have taken a complementary approach, that of reconstructing a group of 15 bipolar neurons from serial electron micrographs taken within a small region of a single retina. The patterns of synaptic contact formed by bipolar neurons of specific morphology and cytology were studied quantitatively. The associations we observed among morphology, cytology, and synaptic patterns permitted us to sort the group of 15 neurons into eight types. In the absence of variation due to differences in eccentricity and differences between animals, the individual members of certain types were remarkably regular in morphology and synaptic circuitry. The bipolar cell types described here match rather well the categories recognized by Golgi impregnation (Famiglietti, 1981; Kolb et al., 1981) and by intracellular recording followed by injection of horseradish peroxidase (Kolb and Nelson, 1983; Nelson and Kolb, 1983). The resulting classification scheme for bipolar cell types has formed the basis for subsequent study of the connections of specific types of bipolar neurons with $\beta$ (X) ganglion cells (B. A. McGuire, J. K. Stevens, and P. Sterling, manuscript in preparation).

\section{Materials and Methods}

Tissue preparation and photography. In a normal adult cat anesthetized with Nembutal, the sclera of one eye was slit and the animal was perfused with a mixture of $1 \%$ glutaraldehyde/1\% paraformaldehyde 


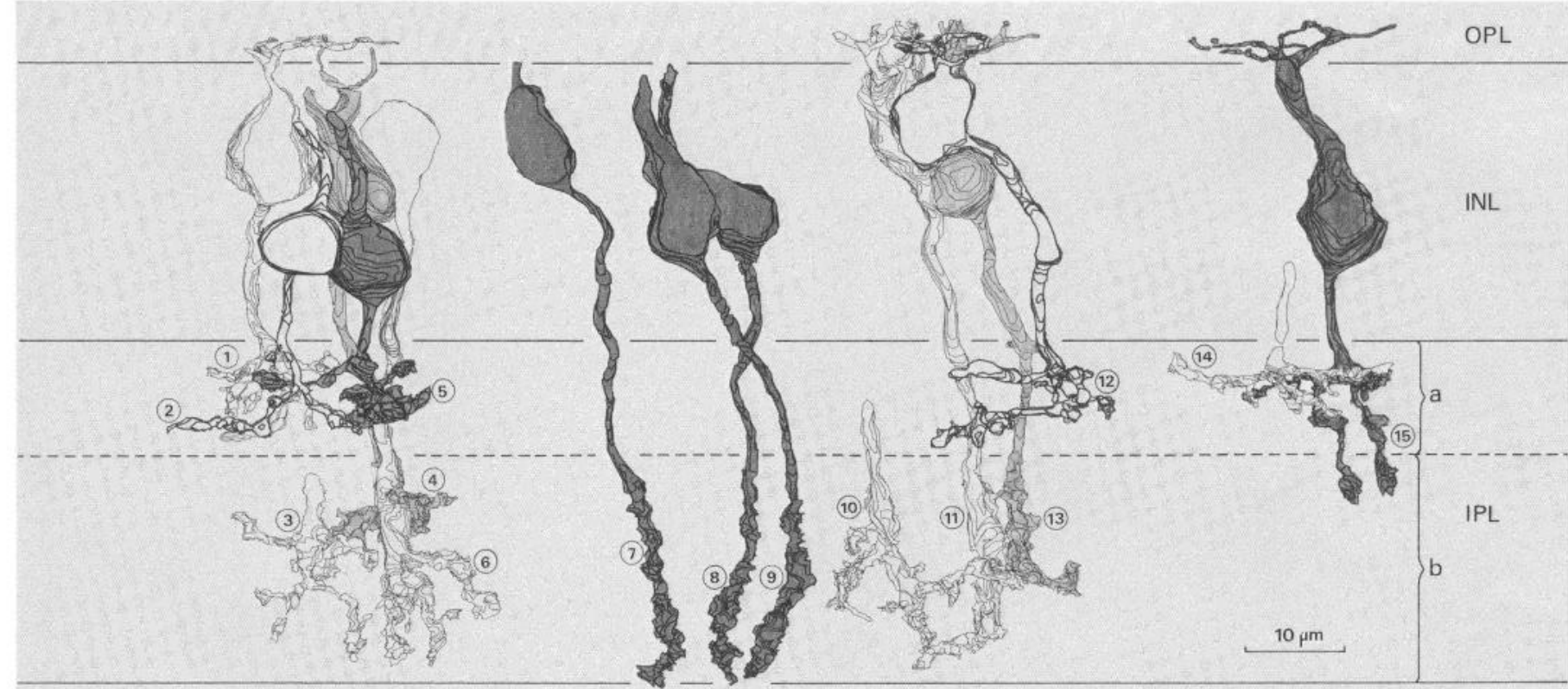

Figure 4. Computer reconstructions of the 15 bipolar cells placed as they appeared in the series. Shaded cells have darker cytoplasm. The numbers represent $\mathrm{RB}$ cells $7,8,9 ; \mathrm{CBb}_{1}$ cells $3,6,10$, and $11 ; \mathrm{CBb}_{2}$ cell $4 ; \mathrm{CBb}_{3}$ cell $13 ; \mathrm{CBa}_{1}$ cells 1 and $14 ; \mathrm{CBa}_{2}$ cells 5 and $15 ; \mathrm{CBa}_{3}$ cell 12 ; and $\mathrm{CBa}_{4}$ cell 2. $G C L$, ganglion cell layer; $I N L$, inner nuclear layer; $I P L$, inner plexiform layer; $O P L$, outer plexiform layer.

\section{TABLE I}

Morphological characteristics of sublamina b bipolar cells

Soma diameter, measured on the front view of each cell, was the maximum diameter on an axis parallel to retinal layers. Soma position was measured from the vitreal side of the soma. Primary axonal and dendritic diameters were estimated as typical diameter of process shortly after it was emitted from the soma.

\begin{tabular}{|c|c|c|c|c|c|c|c|c|c|}
\hline & \multicolumn{3}{|c|}{$\mathrm{RB}^{a}$} & \multicolumn{4}{|c|}{$\mathrm{CBb}_{1}$} & \multirow{2}{*}{$\begin{array}{c}\mathrm{CBb}_{2} \\
4 \\
\end{array}$} & \multirow{2}{*}{$\begin{array}{c}\mathrm{CBb}_{3} \\
13 \\
\end{array}$} \\
\hline & $7^{b}$ & 8 & 9 & 11 & 6 & 10 & 3 & & \\
\hline Soma diameter $(\mu \mathrm{m})$ & 6.2 & 6.7 & 7.6 & 8.7 & $>7.9$ & $--^{c}$ & - & 7.8 & 8.5 \\
\hline $\begin{array}{l}\text { Primary dendritic diameter } \\
(\mu \mathrm{m})\end{array}$ & - & 1.3 & 2.0 & 1.6 & - & - & - & 3.4 & 3.2 \\
\hline Primary axon diameter $(\mu \mathrm{m})$ & 1.1 & 1.2 & 1.2 & 1.6 & 1.4 & - & - & 1.8 & 1.4 \\
\hline Cytoplasm density & \multicolumn{3}{|c|}{ Very dark } & \multicolumn{4}{|c|}{ Pale } & Medium & Medium \\
\hline
\end{tabular}

${ }^{a}$ Cell type.

${ }^{b}$ Cell number.

${ }^{c}$-, Measurement unavailable due to incomplete reconstruction.

${ }^{d}$ IPL, inner plexiform layer.

$(200 \mathrm{ml})$ followed by $2 \%$ glutaraldehyde/ $\%$ paraformaldehyde $(800$ $\mathrm{ml}$ ). The aldehyde solutions were dissolved in $0.12 \mathrm{M}$ phosphate buffer at a $\mathrm{pH}$ of 7.4. The next day the retina was osmicated, stained en bloc with uranyl acetate ( $4 \%$ in sodium maleate buffer), dehydrated through a series of methanols, and embedded in Epon. We cut a series of 189 silver to silver-gold radial sections (estimated $0.075 \mu \mathrm{m}$ thick) on a Sorvall MT-2B microtome, mounting the sections on slot grids and staining further with uranyl acetate and lead citrate. Each section was photographed on a JEOL $100 \mathrm{~B}$ microscope at $120 \mathrm{kV}$. Six overlapping micrographs were taken of each section (Fig. 1) at about $\times 1600$ to cover an area of about $100 \times 120 \mu \mathrm{m}$ (Fig. 2).

Reconstruction. Bipolar cells were reconstructed using a computerassisted video system designed for rapid viewing of corresponding areas in adjacent sections and for easy digitizing of cell profiles. This system is described in detail by Stevens et al. (1980a). Briefly, the EM negatives of a particular area were roughly aligned and copied onto a $35 \mathrm{~mm}$ filmstrip which was viewed through a microscope and displayed on a microprocessor-controlled, high resolution video monitor. The profiles of a bipolar cell were followed within a section by moving the filmstrip laterally $(\mathrm{X}, \mathrm{Y})$ by means of stepping motors and between sections by advancing the filmstrip. The $\mathrm{X}, \mathrm{Y}$ coordinates within a section and section number for each profile were recorded on the computer. We aligned the corresponding profiles in adjacent sections using small structures such as mitochondria as fiducials, and then digitized all of the profiles. Also recorded were the positions and identities of all preand postsynaptic profiles. The data were transferred to a PDP 11/34 computer which "stacked" the profiles in register and removed hidden lines to provide an image of the whole cell. The illustrations display every synaptic contact, rather than "hiding" the ones which are on the rear surface of the cells. The reconstruction procedure appears to represent quite faithfully the actual shape of these neurons because there were striking similarities between our reconstructions and the morphology of particular bipolar cells described by Golgi impregnation. 


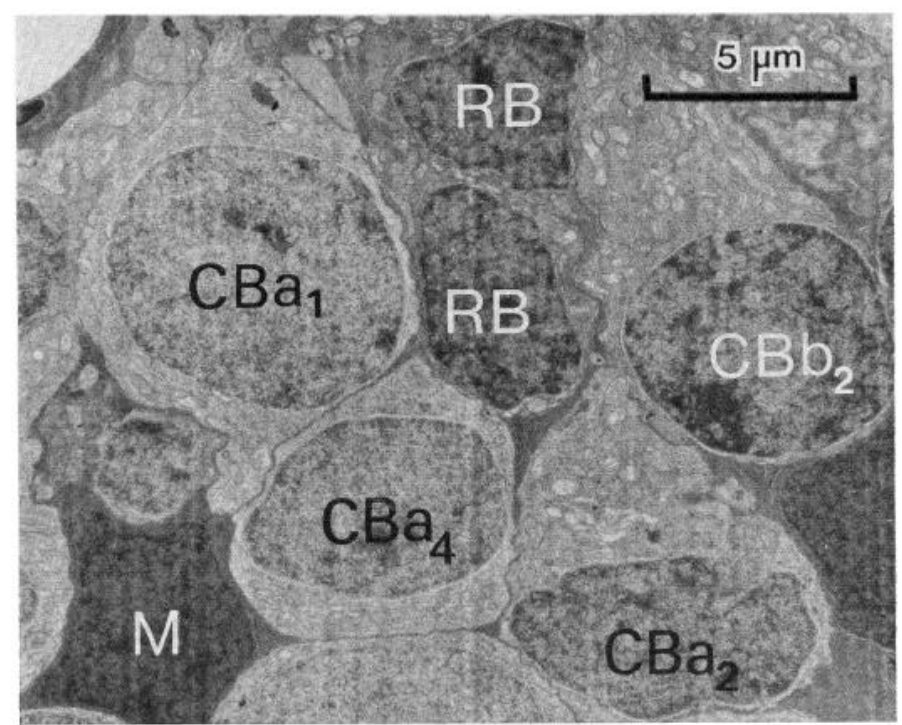

Figure 5. Electron micrograph shows variability in cytology of different bipolar cell somas. $\mathrm{CBa}_{1}$ and $\mathrm{CBa}_{4}$ appear pale; $\mathrm{CBa}_{2}$ is somewhat darker; the nucleus of $\mathrm{CBb}_{2}$ is darker than that of $\mathrm{CBa}_{2}$; and $\mathrm{RB}$ is the darkest, but not as dark as the Müller cell $(M)$.

\section{Results}

Fifteen bipolar cell axons were partially reconstructed from a strip of retina $14 \times 120 \mu \mathrm{m}$. In this region, the cells in the ganglion cell layer formed a solid tier (from one to two cells thick; see Fig. 1). There were 10,500 cells $/ \mathrm{mm}^{2}$ which placed this patch of retina within the area centralis, about $2^{\circ}$ from its center (unpublished results; see Fig. 3). Although we focused on characterizing the axonal arborizations, for 12 cells the soma was also reconstructed, and for two, dendrites were reconstructed to their tips (Fig. 4). Particular attention was devoted to identifying all of the synaptic contacts made by each bipolar cell axon and to determining the strata of the inner plexiform layer (S1 to S5) in which each arborized. Because we reconstructed a small portion of the bipolar cells in this strip of retina (perhaps 5 to $20 \%$ of the total), it was not possible to determine the relative abundance of any one type.

Profiles in the inner plexiform layer were identified according to previously published criteria (see, for example, Dowling and Boycott, 1966; Kolb, 1979; Stevens et al., 1980b). Thus, presynaptic profiles with synaptic vesicles and synaptic ribbons were called "bipolar;" those with vesicles and making conventional contacts were called "amacrine." Amacrine cells presynaptic and postsynaptic to the same bipolar cell (even if not in the same section) were called "reciprocal." Postsynaptic profiles lacking vesicles but containing microtubules and clusters of ribosomes were called "ganglion cell dendrites." Ganglion cell dendrites with dark cytoplasm always belonged, when traced to a soma, to a $\beta$ cell. The largest dendrites with pale cytoplasm were probably from $\alpha$ cells (Stevens et al., 1980b). In the outer plexiform layer, pale profiles with synaptic vesicles and conventional contacts onto bipolar cell processes are believed to be largely from interplexiform cells (Kolb and West, 1977; Nakamura et al., 1980), and we have referred to them that way.

\section{Rod bipolar cells}

The axons of three rod bipolar cells ( $\mathrm{RBs}$ ) were reconstructed in their entirety. These were not traced to their connections with the rod spherule but were identified by comparison to previous descriptions (Kolb and Famiglietti, 1974; Kolb, 1979). The rod bipolar cell somas were 6.2 to $7.6 \mu \mathrm{m}$ in diameter (Table I), smaller than those of cone bipolar neurons, and pyriform with a single gradually tapering dendrite ascending toward the outer plexiform layer. Their cytoplasm was distinctively dark (as in Fig. 5), but not so dark as the cytoplasm of Müller cells. The axons, curving slightly, descended through sublamina a without branching. Upon reaching sublamina $b$ (stratum 3), each axon thickened somewhat, assumed a scalloped contour, and began to make many synaptic contacts (Figs. 6 and 7). The frequency of these contacts increased as the rod bipolar cell axons passed through strata 4 and 5 where, at the edge of the ganglion cell layer, the axons terminated (Fig. 6).

The three rod bipolar cell axons received, respectively, 35, 39 , and 42 inputs from amacrine cells (Table II). In each case almost exactly $70 \%(69 \%, 69 \%, 71 \%)$ of the contacts were from reciprocal amacrine cell varicosities, the remainder being from nonreciprocal profiles. Although all of these presynaptic varicosities resembled one another, it is known that the reciprocal ones derive from at least four specific types of amacrine (Kolb and Nelson, 1983), all of which accumulate GABA (Freed and Sterling, 1982; Pourcho and Goebel, 1983) and possibly indoleamine (Holmgren-Taylor, 1982).

The rod bipolar neurons provided outputs at, respectively, 27,28 , and 32 synaptic ribbons. Almost invariably a ribbon was presynaptic to two processes (Table III) and thus formed the classic "dyad" arrangement described by Kidd (1962), Dowling and Boycott (1966), and Kolb (1979). In virtually every case one member of the dyad belonged to a reciprocal amacrine cell process. The other member, when it could be identified, always belonged to an AII amacrine cell. Thus, of the 65 ribbon contacts where both postsynaptic profiles were identified, 64 were onto a pair of amacrine cell profiles. At 23 of the 87 dyads examined, the nonreciprocal postsynaptic process resembled the slender portion of AII cell processes but was lost before the identification was secure. In the best case, however, where $94 \%$ of the postsynaptic profiles were identified, every postsynaptic process belonged to an amacrine cell, $46 \%$ being reciprocal and $48 \%$ being AII. As a rule, therefore, each rod bipolar cell ribbon contact was made with a pair of amacrine cell processes: the AII process, and a varicosity which in every case returned a synapse to the rod bipolar cell. Rod bipolar cells occasionally contacted ganglion cell dendrites. Cell 7 , for example, directed one ribbon contact to a pale ganglion cell dendrite (Fig. $7 \mathrm{~A}$ ) and two other rod bipolars (not reconstructed) each provided one contact to another pale ganglion cell dendrite (Fig. $7 B$ and $C)$. Both postsynaptic dendrites were medium to large in caliber. Although direct rod bipolar-to-ganglion cell contacts were known to exist in rabbit retina (Raviola and Raviola, 1967), this is the first report of such connections in the cat.

The three reconstructed rod bipolar cells differed somewhat in the proximity of their somas to the inner plexiform layer and in the form of the soma and proximal dendrite, but for other features they exhibited remarkable constancy. Their cytology and axon morphology were indistinguishable. Thus, the depth in the inner plexiform layer at which the axons began to make synapses was constant to within $\pm 2 \mu \mathrm{m}$, and the synaptic patterns of the three axons were virtually identical.

\section{Cone bipolar cells arborizing in sublamina $b$}

Six cone bipolar cells with axons arborizing in sublamina $b$ were partially reconstructed. These proved to be of three types, which we have called $\mathrm{CBb}_{1}, \mathrm{CBb}_{2}$, and $\mathrm{CBb}_{3}$.

$C B b_{1}$. There were four examples of this type, of which cell 11 was most complete (Fig. 8). The soma of cell 11, located high in the inner nuclear layer, was oval $(8.5 \times 11.2 \mu \mathrm{m})$ with pale cytoplasm. Four thin dendrites extended from the upper pole to ramify among the cone pedicles, but the nature of the contacts with cones could not be determined. There were two synaptic contacts on these dendrites from the interplexiform cell.

The axon descended as a single, pale process (about $1.4 \mu \mathrm{m}$ 
$\mathrm{RB}$

OPL
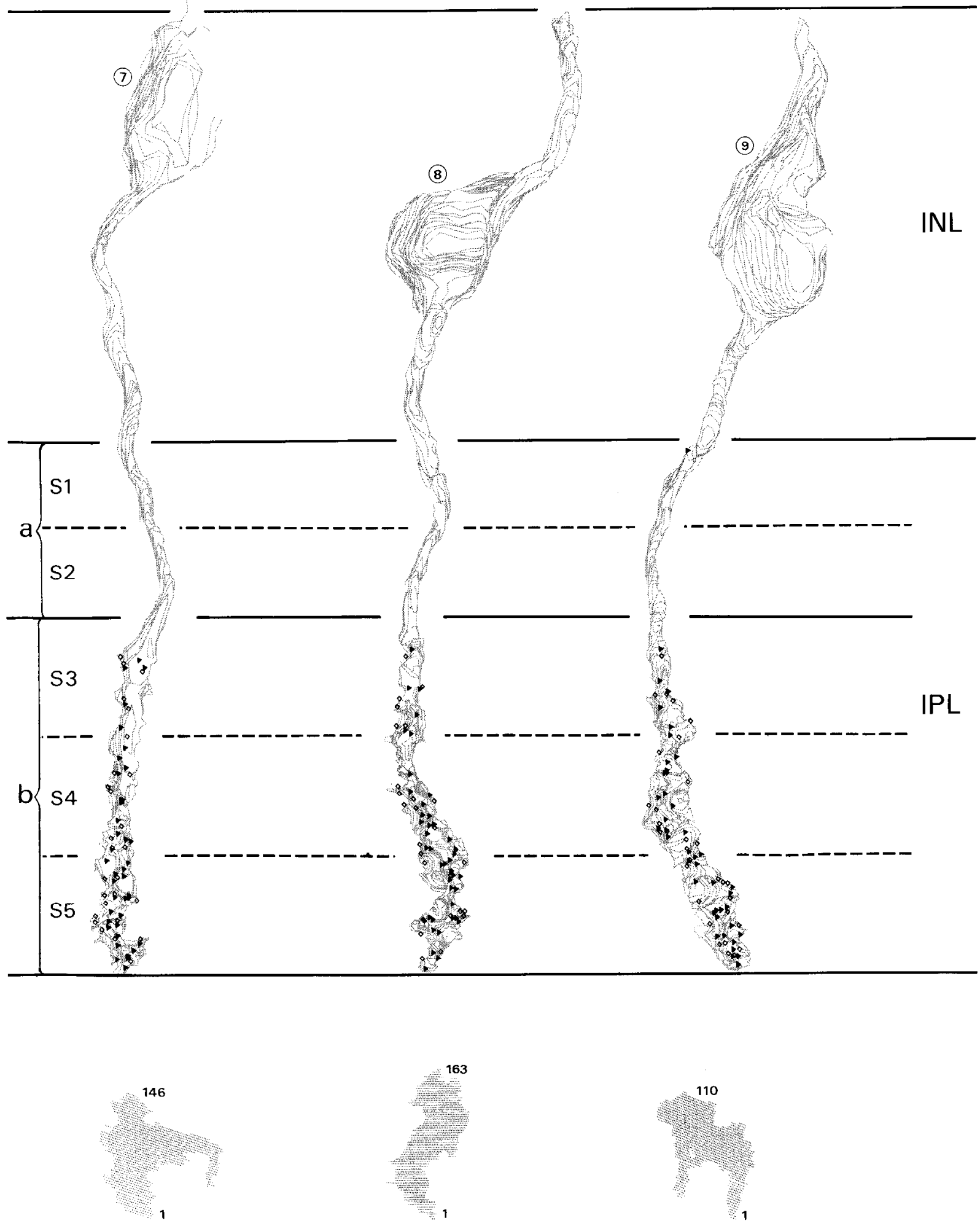

$10 \mu \mathrm{m}$

Figure 6. Rod bipolar (RB) reconstructions. At the hottom, axons rotated $90^{\circ}$ about the $\mathrm{X}$ axis with the first and last section numbers indicated. The sublamina $a / b$ border was marked in sections by the presence of AII lobular appendages above the border (top one-third), and rod bipolar ribbon synapses below (bottom two-thirds). Strata 1 and 2 were each half of $a$, and strata 3 to 5 were each one-third of $b$. The slender axons pass through sublamina a and then widen and become scalloped upon entering sublamina $b$ where they receive inputs $(\boldsymbol{\Lambda})$ and make outputs $(\diamond)$. $I N L$, inner nuclear layer; IPL, inner plexiform layer; $O P L$, outer plexiform layer. 


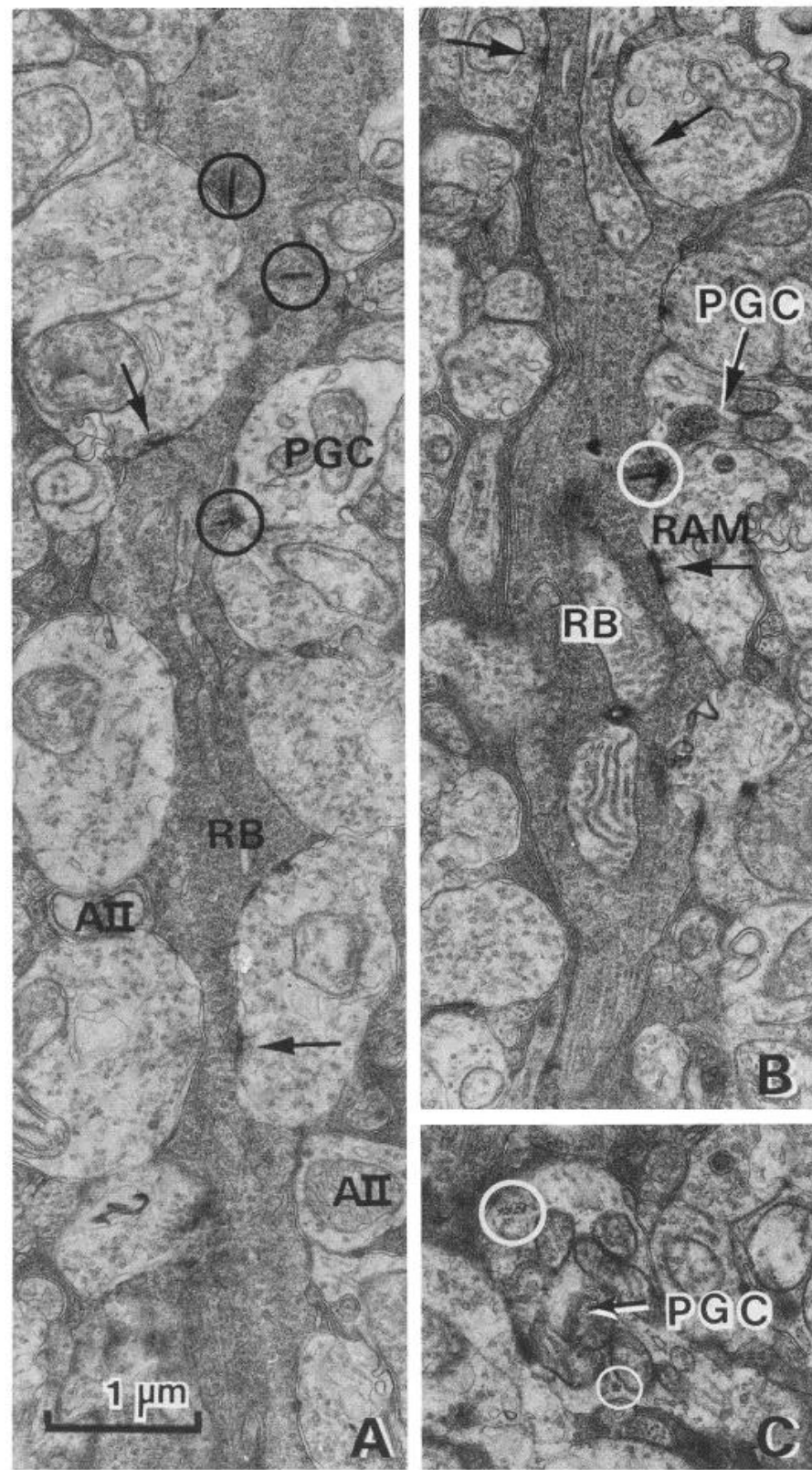

Figure 7. Electron micrographs of RB axons in sublamina b. A, RB (cell 7) contacted a pale ganglion cell $(P G C)$ identified in other sections by ribosome clusters. Synaptic ribbons are circled. Arrows, varicose amacrine inputs. $A I I$, AII amacrines postsynaptic in other sections. $B$, Another RB contacting a pale ganglion cell and reciprocal amacrine $(R A M)$ at synaptic ribbon (circle). $C$, The same pale ganglion cell dendrite as in $B$, but in a different section, has prominent ribosome clusters (circles).

in diameter) through sublamina a without making any synaptic contacts. Upon entering sublamina b, the axon swelled to $3 \mu \mathrm{m}$ and began to make synaptic contacts within the neuropil (Fig. $9 A$ ). In stratum 4 it emitted several thin processes that descended into stratum 5 . The other three $\mathrm{CBb}_{1}$ axons were also pale and vertically oriented through strata 3 to 5 . Ten percent of the contacts of these bipolars were made in stratum $3,60 \%$ in stratum 4 , and $30 \%$ in stratum 5 . The endings of these $\mathrm{CBb}_{1}$ axons and also axons of the other types of cone bipolar cells in sublamina $\mathrm{b}$ were invaginated by fine ganglion cell and amacrine cell processes (Fig. 9A and $B$ ); none of the bipolar cell axons in sublamina a bore such invaginations.

The $\mathrm{CBb}_{1}$ axon terminals received many chemical synaptic contacts from amacrine cells. The most extensively reconstructed axon, that of cell 6 , received 63 such contacts. Threefourths of these were from nonreciprocal amacrine cells, i.e., those that provide input to the bipolar cell but do not in turn receive it. The rest of the contacts, roughly one-fourth, were from reciprocal amacrine cell profiles, which, as dyad members, received ribbon-related contacts from the bipolar cell. $\mathrm{CBb}_{1}$ cone bipolar cell axons received numerous extensive gap junction contacts, mainly within strata 4 and 5 , from the processes of AII amacrine cells. Cells 6 and 11 each received six such contacts, whereas cells 3 and 10 , which were less extensively reconstructed, received three apiece. Since most, and perhaps all, of the gap junctions on cell 11 were with the branches of a single AII cell, there was evidence for very little divergence in the connections between AII and $\mathrm{CBb}_{1}$ cells.

The $\mathrm{CBb}_{1}$ axon terminals provided output at synaptic ribbons to numerous postsynaptic profiles. There were 88 ribbon outputs from the most extensively reconstructed axon (cell 6) and no fewer than 75 ribbon contacts for the others. Of the profiles that could be identified as being postsynaptic to $\mathrm{CBb}_{1}$ axons, $40 \%$ belonged to amacrine cells and $60 \%$ belonged to ganglion cells. Of the 53 ribbon synapses from cell 6 in which both members of the postsynaptic dyad could be identified, 41 were onto a ganglion/amacrine cell pair; 11 were onto a ganglion/ ganglion cell pair; and 1 was onto an amacrine/amacrine cell pair. Combining the data from all four $\mathrm{CBb}_{1}$ axons, 162 dyads were ganglion/amacrine; 42 were ganglion/ganglion; and 1 was amacrine/amacrine. About one-third of the amacrine cell profiles were reciprocal to the $\mathrm{CBb}_{1}$ axon, but the remainder received input without reciprocating. $\mathrm{CBb}_{1}$ cells contacted at least three morphologically different amacrine cell profiles. One kind was a 1 - to $2-\mu \mathrm{m}$-wide varicosity which constricted to very thin necks at each end. A second was pale, oriented radially in sublamina $\mathrm{b}$, and less varicose, with swellings $2 \mu \mathrm{m}$ at most in diameter; the connections between these varicosities were larger and thus easier to follow than the first type, allowing us in one case to follow about half a dozen interconnected varicosities which received 8 ribbon contacts from a single bipolar cell. The third amacrine cell variety, which received 5 contacts from one $\mathrm{CBb}_{1}$ cell, was a straight, thin $(0.5$ to $1.0 \mu \mathrm{m}$ in diameter) process traveling tangentially within stratum 3 , making occasional punctate synapses onto very fine postsynaptic profiles $(<0.5 \mu \mathrm{m}$ in diameter $)$. The ganglion cell dendrites receiving $\mathrm{CBb}_{1}$ input were divided about evenly between dark and pale varieties.

The axons of $\mathrm{CBb}_{1}$ showed the same regularities of feature as those of the rod bipolar cells. All four $\mathrm{CBb}_{1}$ axons swelled and commenced to make synapses at the same depth in stratum 3 . Their cytoplasm was pale, and the form of their arborizations in strata 4 and 5 was similar, as were, in quantitative detail, their patterns of synaptic connection. Such evidence of regularity within two types suggested that if any two bipolar cells differ appreciably, they are likely to represent different types. This reasoning led us to distinguish two additional types of cone bipolar cell axons in sublamina b, even though only a single example of each was reconstructed.

$C B b_{2}$. The soma of cell 4 was smaller in diameter $(7.8 \mu \mathrm{m})$ than that of any of the other cone bipolar cells and was located in the middle of the inner nuclear layer (Fig. 10). It was pyriform with a single primary dendrite ( $3 \mu \mathrm{m}$ in diameter) tapering gradually toward the outer plexiform layer (Fig. 10). The cytoplasm was medium-dark (Fig. 5). The axon was darker than those of adjacent $\mathrm{CBb}_{1}$ cells but paler than those of neighboring rod bipolars. From the middle of stratum 2 to the middle of stratum 3 , the axon gradually thickened to about 2.2 $\mu \mathrm{m}$ in diameter. In the middle of stratum 3 , it divided into three branches that arborized in lower stratum 3 and upper stratum 4 where most of its synaptic contacts were located. 
TABLE II

Inputs to bipolar cells of sublamina $b$

Numbers of specific inputs are described as percentages of the total number of inputs. AII amacrine cells were morphologially distinguishable from other amacrine cells. Other presynaptic amacrine profiles were called reciprocal if they were also postsynaptic to the same bipolar cell.

\begin{tabular}{|c|c|c|c|c|c|c|c|c|c|}
\hline & \multicolumn{3}{|c|}{$\mathrm{RB}^{a}$} & \multicolumn{4}{|c|}{$\mathrm{CBb}_{1}$} & \multirow{2}{*}{$\frac{\mathrm{CBb}_{2}}{4}$} & \multirow{2}{*}{$\frac{\mathrm{CBb}_{3}}{13}$} \\
\hline & $7^{b}$ & 8 & 9 & 11 & 6 & 10 & 3 & & \\
\hline \multicolumn{10}{|l|}{ Source of inputs } \\
\hline AII amacrine & 0 & 0 & 0 & 0 & 0 & 0 & 0 & 0 & 0 \\
\hline $\begin{array}{l}\text { Nonreciprocal ama- } \\
\text { crine }\end{array}$ & $31 \%$ & $29 \%$ & $31 \%$ & $76 \%$ & $70 \%$ & $72 \%$ & $75 \%$ & $44 \%$ & $80 \%$ \\
\hline AII gap junctions & 0 & 0 & 0 & 6 & 6 & 3 & 3 & 1 & 3 \\
\hline
\end{tabular}

${ }^{a}$ Cell type.

${ }^{b}$ Cell number.

TABLE III

Outputs from bipolar cells of sublamina $b$

Outputs are described for each bipolar cell as percentages of its total postsynaptic processes, usually equal to twice the number of ribbon contacts since bipolar cells are typically presynaptic to two processes at each synaptic ribbon.

\begin{tabular}{|c|c|c|c|c|c|c|c|c|c|}
\hline & \multicolumn{3}{|c|}{$\mathrm{RB}^{a}$} & \multicolumn{4}{|c|}{$\mathrm{CBb}_{1}$} & \multirow{2}{*}{$\frac{\mathrm{CBb}_{2}}{4}$} & \multirow{2}{*}{$\frac{\mathrm{CBb}_{3}}{13}$} \\
\hline & $7^{b}$ & 8 & 9 & 11 & 6 & 10 & 3 & & \\
\hline \multicolumn{10}{|l|}{ To amacrine cells } \\
\hline Reciprocal amacrine & $50 \%$ & $46 \%$ & $47 \%$ & $11 \%$ & $12 \%$ & $8 \%$ & $8 \%$ & $20 \%$ & $11 \%$ \\
\hline $\begin{array}{l}\text { Nonreciprocal ama- } \\
\text { crine }\end{array}$ & 0 & 0 & 0 & $18 \%$ & $18 \%$ & $24 \%$ & $25 \%$ & $17 \%$ & $26 \%$ \\
\hline Total Amacrine & $82 \%$ & $94 \%$ & $86 \%$ & $29 \%$ & $30 \%$ & $32 \%$ & $33 \%$ & $37 \%$ & $37 \%$ \\
\hline Dark ganglion cell & 0 & 0 & 0 & $21 \%$ & $33 \%$ & $23 \%$ & $27 \%$ & $34 \%$ & $15 \%$ \\
\hline Pale ganglion cell & $2 \%$ & 0 & 0 & $31 \%$ & $16 \%$ & $19 \%$ & $20 \%$ & $4 \%$ & $32 \%$ \\
\hline Total ganglion cell & $2 \%$ & 0 & 0 & $52 \%$ & $49 \%$ & $42 \%$ & $47 \%$ & $38 \%$ & $47 \%$ \\
\hline Unidentified & $16 \%$ & $6 \%$ & $14 \%$ & $19 \%$ & $21 \%$ & $26 \%$ & $20 \%$ & $25 \%$ & $16 \%$ \\
\hline Total & $100 \%$ & $100 \%$ & $100 \%$ & $100 \%$ & $100 \%$ & $100 \%$ & $100 \%$ & $100 \%$ & $100 \%$ \\
\hline Total no. of ribbons & 27 & 28 & 32 & 87 & 88 & 83 & 75 & 57 & 59 \\
\hline
\end{tabular}

${ }^{a}$ Cell type.

${ }^{b}$ Cell number.

Cell 4 received 54 chemical contacts from amacrine cell profiles, which were almost equally divided between reciprocal ones which also received ribbon inputs from cell 4 and nonreciprocal ones which did not. This cone bipolar cell also received a single, small gap junction from an AII amacrine cell. Cell 4 provided 57 ribbon contacts to postsynaptic profiles. Threefourths of the postsynaptic processes could be identified as amacrine or ganglion cell. Of the 30 ribbons where both members of the dyad were identifiable, 25 were ganglion/amacrine cell pairs, 3 were ganglion/ganglion cell pairs, and 2 were amacrine/amacrine cell pairs. Amacrine cells received $37 \%$ of the contacts; about half of these postsynaptic amacrine cell profiles had reciprocal, feedback synapses, and the other half were not reciprocally connected. Ganglion cell dendrites received $38 \%$ of the outputs. Almost all of the postsynaptic ganglion cell dendrites were dark, there being only one pale ganglion cell dendrite among the 25 ganglion/amacrine cell dyads.

$C B b_{3}$. The soma of cell 13 was pear shaped, of medium diameter $(8.5 \mu \mathrm{m})$, and located in the middle of the inner nuclear layer (Fig. 10). The cytoplasm was medium-dark. A single, thick primary dendrite extended toward the outer plexiform layer where it divided into six branches. These arborized at the bases of cone pedicles, but the contacts from cones could not be identified. The axon, like that of $\mathrm{CBb}_{2}$, was darker than the $\mathrm{CBb}_{1}$ axons (Fig. 10) and paler than the rod bipolar cell axons. Upon entering the inner plexiform layer, the axon emitted two slender processes which could not be traced. One of these made a pair of synaptic contacts with processes in stratum 1 (Fig. 11). The axon dilated slightly at the junction of strata 2 and 3 and began to make many synapses within the neuropil. The axon twisted into a tangential orientation at the junction of strata 3 and 4, producing three branches that arborized in stratum 4 . Most of the synaptic contacts were located in stratum $4(65 \%)$ rather than in stratum $3(35 \%)$ which was the reverse of the pattern exhibited by $\mathrm{CBb}_{2}$.

Cell 13 received 46 chemical synaptic contacts, which were overwhelmingly $(80 \%)$ from amacrine cell processes which did not themselves receive reciprocal contacts from cell 13. Reciprocal amacrine cell profiles provided the remaining inputs (20\%). This bipolar cell made three small gap junction contacts with AII processes. Cell 13 also provided 59 ribbon contacts to postsynaptic profiles, most of which $(84 \%)$ were identifiable as amacrine or ganglion cells. Of the 44 ribbon synapses in which both members of the dyad were identified, 37 were ganglion/ amacrine cell pairs; 6 were ganglion/ganglion cell pairs; and 1 was an amacrine/amacrine cell pair. Amacrine cell profiles, one-third of which were reciprocally connected to the bipolar cell axon terminal and two-thirds of which were not, received $37 \%$ of the ribbon contacts. Ganglion cells received $47 \%$ of the 

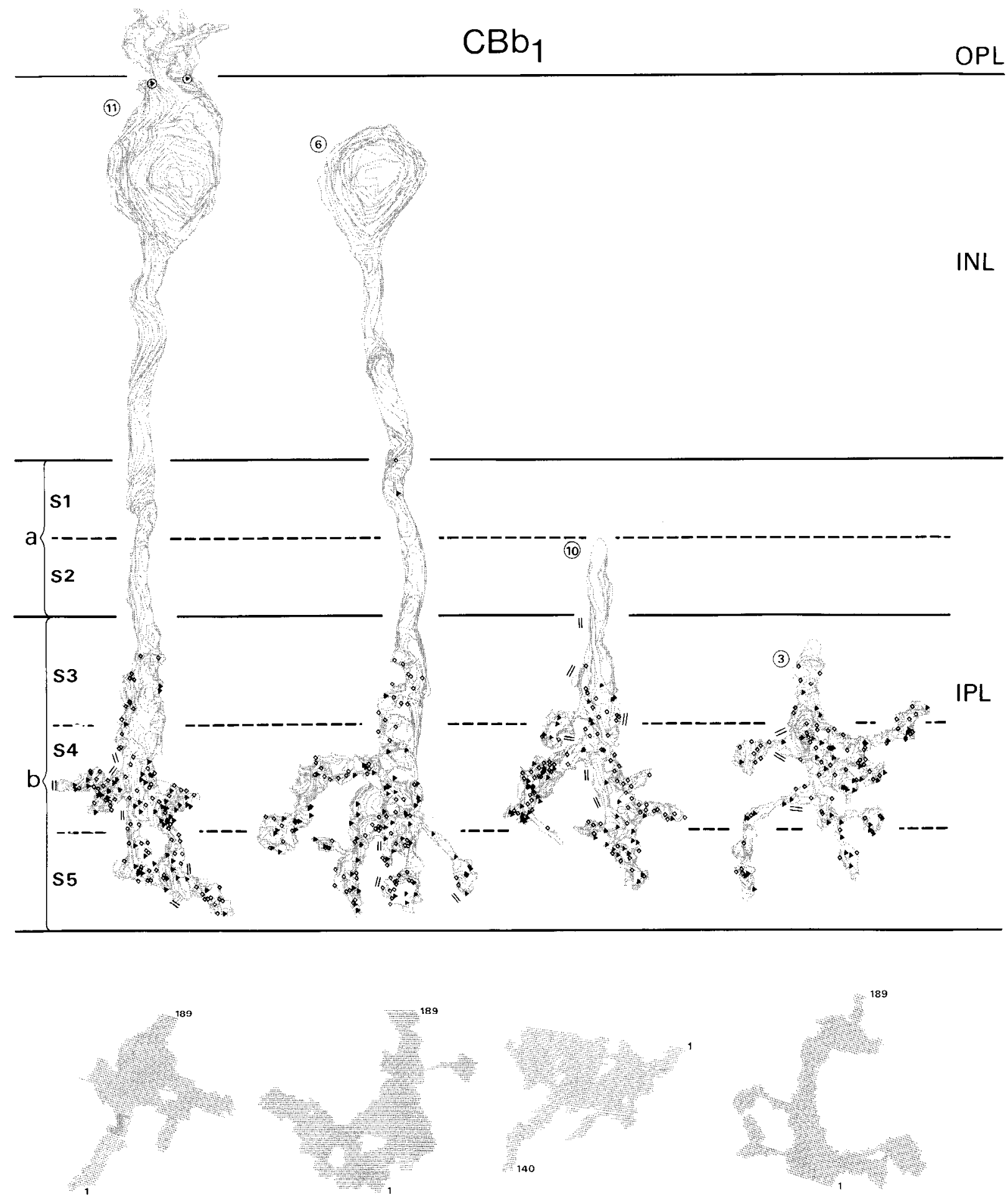

$10 \mu \mathrm{m}$

Figure 8. $\mathrm{CBb}_{1}$ reconstructions. Bottom, Axons rotated $90^{\circ}$ about the $\mathrm{X}$ axis. The axon of $\mathrm{CBb}_{1}$ widens in sublamina b and then emits several thinner, vertical branches. $\diamond$, outputs; $\boldsymbol{\Lambda}$, inputs; $\|$, gap junction with AII amacrine; $\Theta$, interplexiform cell inputs. INL, inner nuclear layer; $I P L$, inner plexiform layer; $O P L$, outer plexiform layer.

ribbon contacts. Two-thirds of these postsynaptic ganglion cell dendrites were pale and the rest were dark. Thus, in contrast to $\mathrm{CBb}_{2}, 24$ of the 37 ganglion/amacrine cell dyads had a pale ganglion cell dendrite as half of the dyad pair.

$\mathrm{CBb}_{2}$ and $\mathrm{CBb}_{3}$ had some features in common, but their differences were more striking. The axons had similar cytoplasmic density (darker than those of $\mathrm{CBb}_{1}$, paler than those of RBs), they arborized in strata 3 and 4 , and the somas were both adjacent to the outer plexiform layer. However, compared to $\mathrm{CBb}_{2}$, the $\mathrm{CBb}_{3}$ soma was larger, and its axon made more 


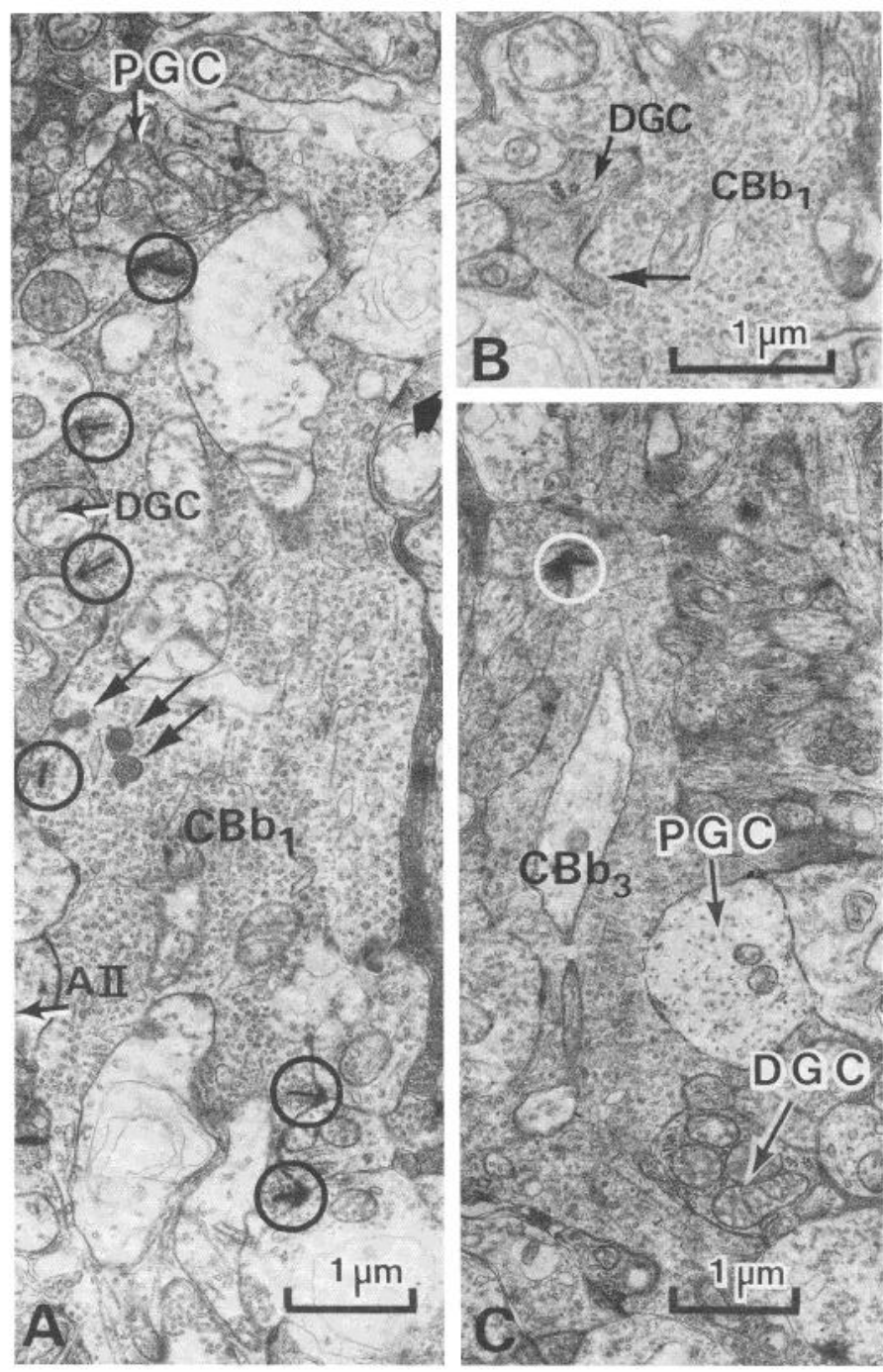

Figure 9. Electron micrographs of $\mathrm{CBb}_{1}$ and $\mathrm{CBb}_{3}$ axons in sublamina b. Circles, synaptic ribbons; $D G C$, dark ganglion cell dendrite; $P G C$, pale ganglion cell dendrite. $A$, Pale axon of $\mathrm{CBb}_{1}$ widens in $\mathrm{S} 3-4$. Small processes (thin arrows) invaginate into the axon. Wide arrow, amacrine input. $B, \mathrm{~A}$ small invagination arises in this case from a dark ganglion cell dendrite $(D G C)$ belonging to an on- $\beta$ cell. $C, \mathrm{CBb}_{3}$ axon is darker and thinner than $\mathrm{CBb}_{1}$. Note pale $(P G C)$ and dark $(D G C)$ ganglion cell dendrites. PGC probably belongs to an $\alpha$ cell; DGC does belong to a $\beta$ cell.

contacts in stratum 4 and fewer in stratum 3 ; it also received more inputs from nonreciprocal amacrine cell profiles and made more outputs to pale ganglion cell dendrites.

\section{Cone bipolar cells arborizing in sublamina a}

Six cone bipolar cells with axons arborizing in sublamina a were partially reconstructed. These proved to be of four types, which we have called $\mathrm{CBa}_{1}, \mathrm{CBa}_{2}, \mathrm{CBa}_{3}$, and $\mathrm{CBa}_{4}$.

$C B a_{1}$. There were two examples of this type, of which cell 1 was more complete. The soma of cell 1 was oval $(8.8 \mu \mathrm{m}$ wide, $11 \mu \mathrm{m}$ high) with pale cytoplasm and was located in the middle of the inner nuclear layer (Table IV). Its single dendrite split into several branches in the outer plexiform layer where one received an interplexiform cell contact (Fig. 12). Another branch arborized near three cones, receiving from one at least three separate "flat" synaptic contacts (Boycott and Kolb, 1973) (Fig. 13). The axon branched immediately upon entering the inner plexiform layer, forming processes which were smooth in contour and pale (Fig. 14). Within strata 1 and 2, it arborized in a bushy knot of processes and made synaptic contacts.

Cell 1 received 28 chemical synaptic contacts from amacrine cells of several types (Table V). Lobular appendages of the AII amacrine cell provided a great proportion of the contacts (43\%). Seven of 12 such inputs were contributed by a single AII amacrine cell. Of the remaining $57 \%$ of the presynaptic amacrine contacts, only $7 \%$ received a reciprocal ribbon synapse back from cell 1 . Cell 1 provided 69 ribbon contacts to postsynaptic processes, three-fourths of which could be identified as either amacrine or ganglion cell (Table VI). Of the 37 ribbons where both members of the dyad were identified, 36 were ganglion/amacrine cell pairs, and 1 was a ganglion/ganglion cell pair. Thirty-four percent of all of the ribbon contacts went to amacrine cell profiles, just over half of which were AII. Although the postsynaptic densities on the AII cell processes were not very pronounced, we counted these AII cell profiles as postsynaptic because they were usually prominent at the dyads, directly opposite the ribbon in each section. Most of the remaining postsynaptic amacrine cell profiles were nonreciprocating terminals, with the small remainder ( $1 \%$ of the total) making reciprocal connections with cell 1 . Forty-one percent of the outputs from cell 1 were to ganglion cell dendrites, twothirds of which were dark.

The axon of cell 14 resembled that of cell 1 in a number of respects but was different in some, raising some question about its correspondence to cell 1 . The two cells were similar in having pale cytoplasm and a smooth axonal contour. The synaptic pattern of cell 14 was also similar to that of cell 1 in that most of the inputs were from nonreciprocal amacrine and AII cells, and few were from reciprocal amacrine cells. The processes postsynaptic to cell 14 were, as for cell 1 , about evenly split between amacrine cells and ganglion cells, with 28 ganglion/amacrine cell dyads, 1 ganglion/ganglion cell dyad, and 2 amacrine/amacrine cell dyads out of 31 fully characterized ribbon contacts. The axon of cell 14 differed from that of cell 1 in certain respects. The axon arborization was radiating in form rather than bushy, with a somewhat wider field (Fig. 12). The arborization was also flatter and restricted almost entirely to stratum 1 . The proportions of synaptic contacts made by the two axons with various cell types, although similar in pattern, were not identical (Tables V and VI). For example, cell 1 was presynaptic to dark ganglion cell dendrites twice as often as to pale dendrites, whereas the distribution for cell 14 was almost the reverse. However, since a portion of the unidentified postsynaptic processes was likely to consist of slender, pale ganglion cell dendrites lacking obvious ribosomes, these synaptic differences might conceivably arise from our failure to identify 22 to $25 \%$ of the postsynaptic processes. The differences in axonal stratification may only be apparent because at least half of cell 14 's arborization was cut away before the series began (see Fig. 12 , rotated view, bottom), so that cell 14 may have actually had some processes in stratum 2 . On the other hand, it is less likely that the differences in the radiating versus bushy axonal arbors could arise in this way. Additional examples will be needed to determine whether these subtle differences in form and connectivity represent variation within a type or the existence of an additional type.

$\mathrm{CBa}_{2}$. There were two examples of this type, of which cell 15 was more complete (Fig. 15). The soma of cell 15 was larger $(8.9 \mu \mathrm{m}$ in diameter) than those of other cone bipolars and was located in the center of the inner nuclear layer. The soma cytoplasm was darker than the cytoplasm of the other cone bipolar cells but lighter than that of rod bipolar or Müller cells (Fig. 5, cell 5). The dendrites of cell 15 received ribbon-related (invaginating) contacts from cones (Fig. 16). Five ribbon contacts were made by two different cone pedicles. This is the first 

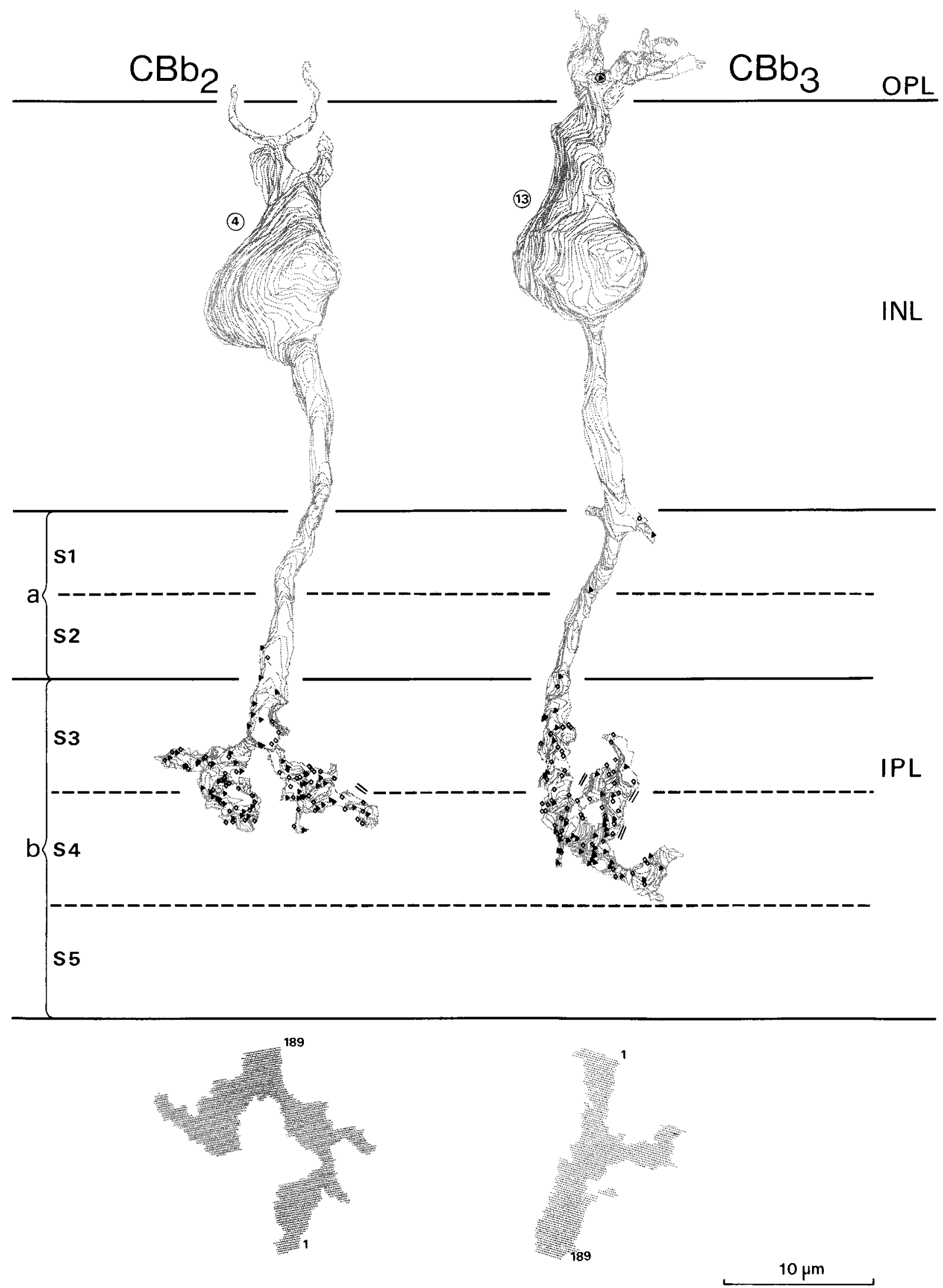

Figure 10. $\mathrm{CBb}_{2}$ and $\mathrm{CBb}_{3}$ reconstructions. Bottom, Axons rotated $90^{\circ}$ about the $\mathrm{X}$ axis. Both are thinner than $\mathrm{CBb}_{1}$ in $\mathrm{S}_{3} . \mathrm{CBb}_{2}$ arborizes primarily in $\mathrm{S} 3 ; \mathrm{CBb}_{3}$ arborizes primarily in $\mathrm{S} 4 . \diamond$, outputs; $\boldsymbol{\Lambda}$, inputs; $\|$, gap junction with AII cell; $\Theta$, interplexiform cell input. INL, inner nuclear layer; $I P L$, inner plexiform layer; $O P L$, outer plexiform layer. 


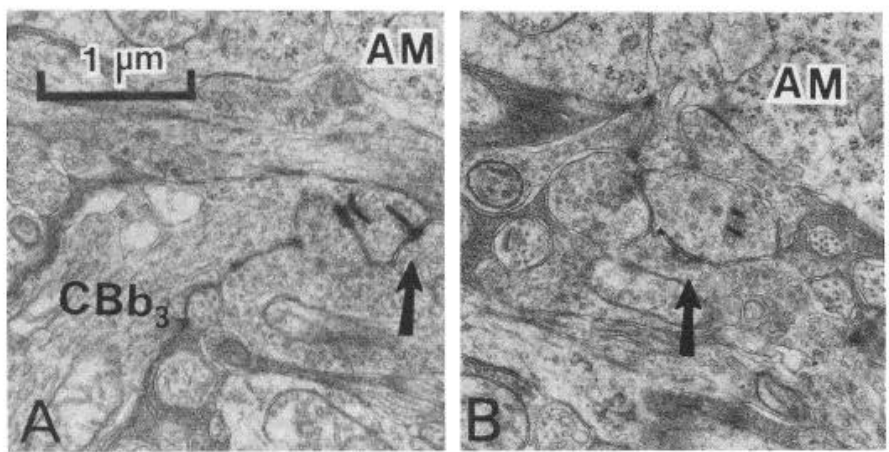

Figure 11. Electron micrograph of $\mathrm{CBb}_{3}$ axon beneath amacrine $(A M)$ somas. $A$, A small branch off of a primary axon contains two synaptic ribbons, one with clear postsynaptic density (arrow). B, Five sections away, the same axon (note synaptic ribbons) receives amacrine input (arrow).

report of a cone bipolar cell arborizing in sublamina a that receives ribbon-related contacts from cones.

The axon branched upon entering the inner plexiform layer (Fig. 15), forming a rather bushy arborization. The dark axonal processes were varicose with swellings ( 2 to $3 \mu \mathrm{m}$ in diameter), which were scalloped and angular in contour, interconnected by thin ( 0.3 to $0.6 \mu \mathrm{m})$ processes (Fig. 17). The axon ramified through strata 1 and 2 and the top part of stratum 3 . Since its lateral extent exceeded the region photographed for the series, the arborization must have been wider than it appears in Figure 15. Most of its synaptic contacts were made within stratum 1.

Cell 15 received 38 chemical synaptic contacts from amacrine cells. Most $(80 \%)$ were from nonreciprocal amacrine cell profiles, the rest (20\%) being from reciprocal amacrine cells which received feedback ribbon contacts from cell 15 . AII amacrine cells provided no contacts to this cell. A total of 47 ribbon contacts were provided to postsynaptic profiles, most of which (79\%) were identifiable as amacrine or ganglion cell. Of 20 fully characterized dyads, 13 were ganglion/amacrine cell pairs, and 7 were amacrine/amacrine cell pairs. Amacrine cells received $33 \%$ of all the ribbon contacts. More than half of the postsynaptic amacrine cells were nonreciprocal; about one-third were reciprocally connected to the bipolar cells; and very few were AII cells. Ganglion cells received most of the ribbon contacts $(46 \%)$, and just over half of these were dark.

Cell 5 resembled cell 15 in soma, dendritic and axonal di- ameter, and cytoplasmic density. The fine morphology of their axons was also similar in that each consisted of scalloped varicosities connected by thin necks. There were also basic similarities in synaptic pattern, such as having much input from nonreciprocal amacrine cells, less from reciprocal amacrine cells, and hardly any from AII amacrines. Of the 25 dyads characterized for cell 5, 24 were ganglion/amacrine cell pairs ( 4 being AII), and 1 was a ganglion/ganglion cell pair. The two cells appeared to differ in their relative numbers of outputs to amacrine and ganglion cells, evident, for example, in the smaller number of contacts between cell 5 and pale ganglion cells compared with cell 15 . This discrepancy can probably be attributed to the higher percentage of unidentified postsynaptic processes for cell 15 , since a certain portion of these presumably belong to slender, pale ganglion cell dendrites which lacked prominent clusters of ribosomes, and further identification would thus bring the numbers into better agreement. The exact proportions of presynaptic reciprocal and nonreciprocal amacrine cell processes also differed, but this could be due to the incompleteness of the reconstruction for cell 15 (Fig. 15). Another difference between the pair was that cell 5 only arborized within strata 1 and 2 , whereas cell 15 reached the top part of stratum 3 . However, both processes of cell 15 that reached stratum 3 contacted the primary branch of an off $\beta$ cell, most of whose input from cell 15 was within strata 1 and 2. Perhaps the "stratification rule" for this axon type is flexible enough to be overridden when there is an opportunity for making particular synaptic connections.

$\mathrm{CBa}_{3}$. The soma of cell 12 was oval with pale cytoplasm and located in the outer part of the inner nuclear layer (Fig. 18). The cell body emitted a single dendrite which divided immediately into at least five branches, one of which received an interplexiform cell contact. The nature of the cone contacts on these dendrites could not be determined. A stout axon emerged from the side of the soma and penetrated 4 to $5 \mu \mathrm{m}$ into the inner plexiform layer before branching laterally (Fig. 19). The arborization was not bushy, but stratified parallel to the retinal layers, with one band in the center of stratum 1 and the other in upper stratum 2. Individual axonal profiles were pale and smooth in contour (Fig. 19) and, therefore, impossible to distinguish in single sections from cross-sections of $\mathrm{CBa}_{1}$ axons. Synaptic contacts between this axon and other neuronal profiles occurred about equally in strata 1 and 2 .

The axon of cell 12 received 34 chemical synaptic contacts from amacrine cell processes. Amacrine cells not reciprocally

TABLE IV

Morphological characteristics of sublamina a bipolar cells ${ }^{a}$

\begin{tabular}{|c|c|c|c|c|c|c|}
\hline & \multicolumn{2}{|c|}{$\mathrm{CBa}_{1}{ }^{b}$} & \multicolumn{2}{|c|}{$\mathrm{CBa}_{2}$} & \multirow{2}{*}{$\begin{array}{c}\mathrm{CBa}_{3} \\
12 \\
\end{array}$} & \multirow{2}{*}{$\begin{array}{c}\mathrm{CBa}_{4} \\
2\end{array}$} \\
\hline & $1^{\mathrm{e}}$ & 14 & 15 & 5 & & \\
\hline Soma diameter $(\mu \mathrm{m})$ & 8.8 & $-^{d}$ & 8.9 & 8.8 & 8.3 & 8.6 \\
\hline $\begin{array}{l}\text { Primary dendritic diameter } \\
(\mu \mathrm{m})\end{array}$ & 1.1 & - & 2.2 & 2.0 & 1.7 & 1.2 \\
\hline $\begin{array}{l}\text { Primary axon diameter } \\
(\mu \mathrm{m})\end{array}$ & 1.4 & - & 1.0 & 0.8 & 1.7 & 0.9 \\
\hline Axon contour & \multicolumn{2}{|c|}{ Smooth } & \multicolumn{2}{|c|}{$\begin{array}{l}\text { Varicose \& } \\
\text { Scalloped }\end{array}$} & Smooth & $\begin{array}{l}\text { Smooth \& } \\
\text { Delicate }\end{array}$ \\
\hline Axon stratification & $\mathrm{S} 1,2$ & $\mathrm{~S} 1$ & $\mathrm{~S} 1,2$ & $\mathrm{~S} 1,2,3$ & $\mathrm{~S} 1,2$ & $\mathrm{~S} 2$ \\
\hline Cytoplasm density & \multicolumn{2}{|c|}{ Pale } & \multicolumn{2}{|c|}{ Dark } & Pale & Pale \\
\hline
\end{tabular}

${ }^{a}$ See Table I legend for measurement criteria.

${ }^{b}$ Cell type.

${ }^{c}$ Cell number.

${ }^{d}$-, Measurement unavailable due to incomplete reconstruction.

e IPL, inner plexiform layer. 

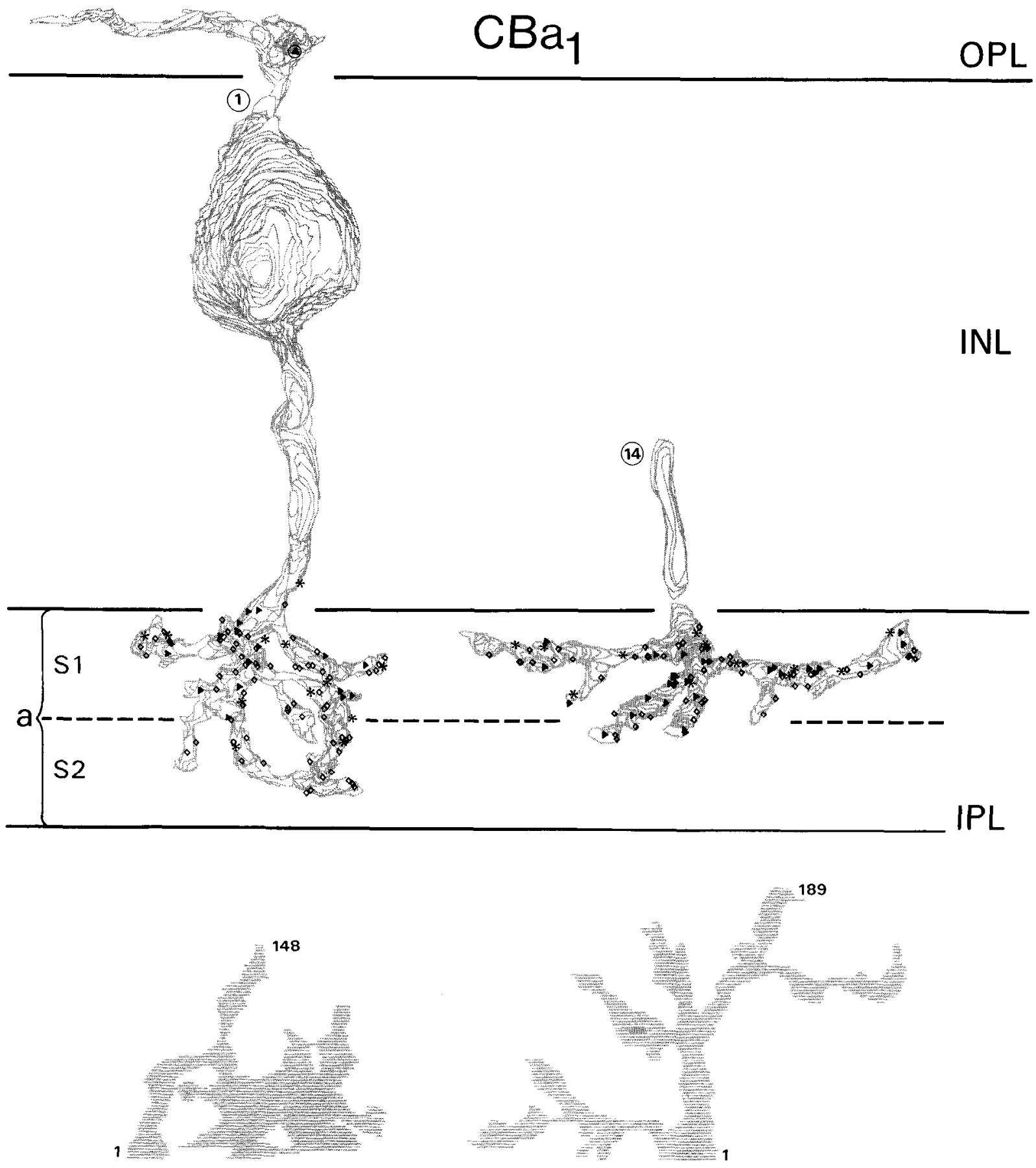

$10 \mu \mathrm{m}$

Figure 12. $\mathrm{CBa}_{1}$ reconstructions. Bottom, Axons rotated $90^{\circ}$ about the $\mathrm{X}$ axis. Both cells had smooth axonal contours and received many AII amacrine inputs $(*) . \diamond$, outputs; $\boldsymbol{\Delta}$, inputs; $($, interplexiform cell input. $I N L$, inner nuclear layer; $I P L$, inner plexiform layer; $O P L$, outer plexiform layer.

connected to the bipolar cell provided the bulk of the contacts $(85 \%)$, while reciprocal amacrine cells comprised the rest. There were no inputs from AII cells. The axon of cell 12 made 47 ribbon contacts onto postsynaptic processes, $79 \%$ of which were identified as amacrine or ganglion cell. Amacrine cells received rather few ribbon contacts $(18 \%$ of the total): most of these were to amacrine cell profiles which did not themselves receive ribbon contacts from cell 12 , with a few to reciprocal and AII amacrines cell processes. Ganglion cell dendrites, divided equally between dark and pale varieties, received the most contacts $(61 \%)$. Of 27 dyads where both members were identified, 17 were ganglion/amacrine cell pairs and 10 were ganglion/ ganglion cell pairs.

$C B a_{4}$. The soma of cell 2 was broader than it was high. It contained pale cytoplasm (Fig. 5) and was located low in the inner nuclear layer (Fig. 18). The primary dendrite ascended without branching halfway to the outer plexiform layer before extending beyond the plane of the series. The axon was delicate and more difficult to trace than those of the other sublamina a cone bipolar cells, so that its arborization within the series is 


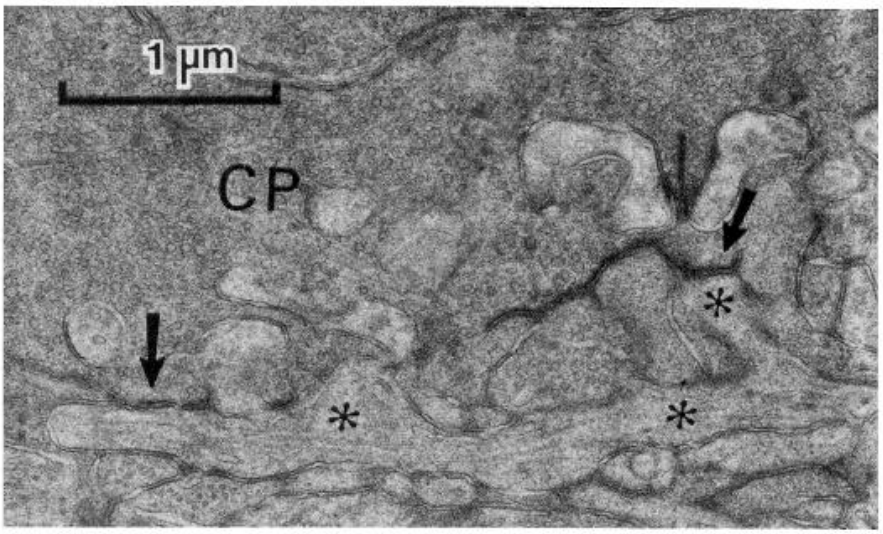

Figure 13. Electron micrograph of $\mathrm{CBa}_{1}$ dendrite $(*)$ from cell 1 receiving flat contacts (arrows) in the outer plexiform layer from the cone pedicle $(C P)$.

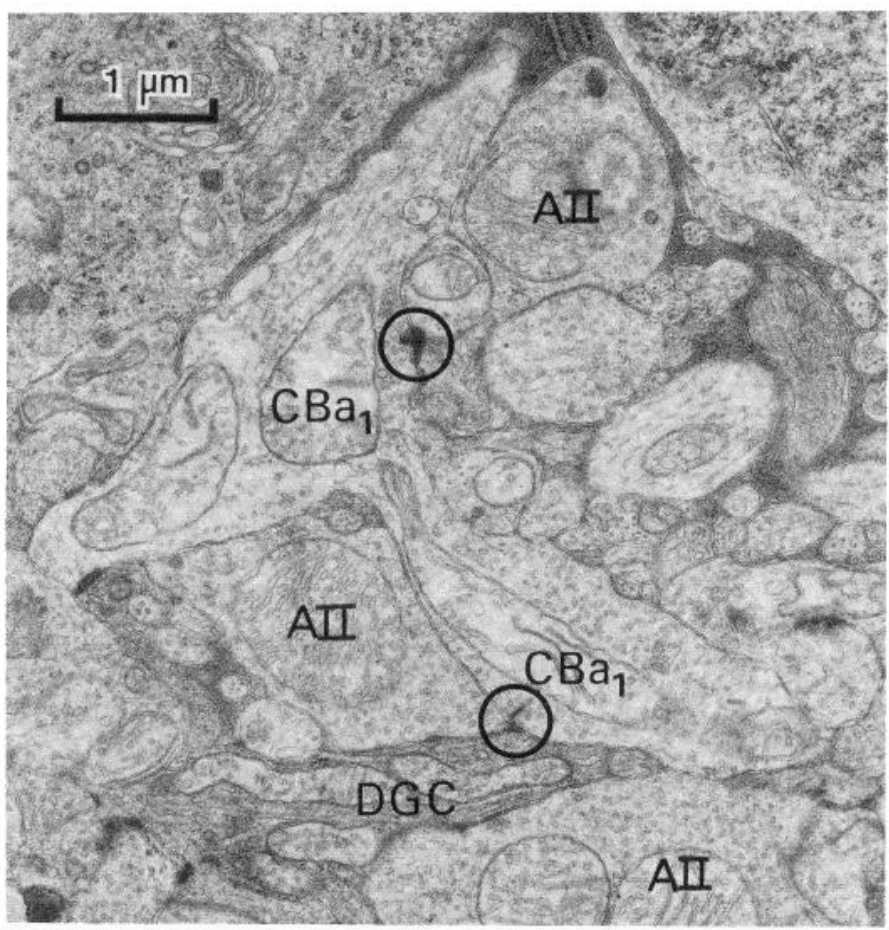

Figure 14. Electron micrograph of pale, smooth $\mathrm{CBa}_{1}$ axon in sublamina a nearby amacrine somas. AII, lobular appendage of AII amacrine cell with characteristic large, pale mitochondria; $D G C$, dark ganglion cell dendrite (belonging to off- $\beta$ cell); circles, synaptic ribbons.

probably more extensive than is shown in Figure 18. The reconstructed portion arborized in lower stratum 2 where it made most of its synaptic connections. Individual axonal profiles were pale and slightly irregular in contour.

The axon of cell 2 received 17 chemical synaptic contacts from amacrine cells. Amacrines receiving reciprocal ribbon contacts from cell 2 provided $59 \%$ of the contacts, a much higher fraction than for any other cone bipolar. Nonreciprocal amacrine cells contributed $29 \%$ of the contacts with a couple ( $12 \%$ ) from AII cells. The axon provided 22 ribbon contacts to postsynaptic profiles, about half of which we identified as amacrine or ganglion cell. Amacrine cells, the major target ( $41 \%$ of the profiles), were divided about equally between reciprocal and nonreciprocal profiles, with none belonging to AII cells. Ganglion cell dendrites received only one-third of the contacts ( $14 \%$ of the total), and almost all of these postsynaptic dendrites were dark.

\section{Patterns of connection from bipolar cells to ganglion cells}

The axons of all three types of cone bipolar cells in sublamina $\mathrm{b}$ contacted the dendrites of on- $\beta$ ganglion cells, and both $\mathrm{CBb}_{1}$ and $\mathrm{CBb}_{3}$ (but not $\mathrm{CBb}_{2}$ ) contacted large, pale dendrites probably belonging to on- $\alpha$ cells. The axons of three of the four types of cone bipolars in sublamina a $\left(\mathrm{CBa}_{1}, \mathrm{CBa}_{2}\right.$ and $\left.\mathrm{CBa}_{4}\right)$ contacted the dendrites of off- $\beta$ cells and pale dendrites probably belonging to off- $\alpha$ cells.

Individual cone bipolar cells commonly directed many ribbon contacts to a single ganglion cell. The greatest number of contacts on a ganglion cell from a single cone bipolar was 47 $\left(\mathrm{CBb}_{1}\right.$ cell 6 to an on- $\beta$ cell, Fig. $\left.20 A\right)$. There were examples of diverging connections, too, in that individual cone bipolar cells sometimes contacted several morphologically different kinds of ganglion cells. In sublamina a, for example, $\mathrm{CBa}_{2}$ (cell 15) contacted an off- $\beta$ cell (Fig. 20G) 23 times and a large, pale dendrite (Fig. 20J) 7 times. From the ganglion cell's point of view, two kinds of convergence were observed. A single ganglion cell received contacts from two cone bipolar cells of the same type. Thus, one on $\beta$ cell (Fig. $20 A$ ) received $69 \mathrm{CBb}_{1}$ contacts, 47 from cell 6 and 22 from cell 3 . A ganglion cell also received contacts from two or more cone bipolar cells of different type. Thus, an on- $\beta$ cell (Fig. $20 E$ ) received 53 contacts from $\mathrm{CBb}_{1}$ and 15 from $\mathrm{CBb}_{3}$. Other examples of these patterns of bipolarto-ganglion cell contact in both sublaminae are illustrated in Figure 20.

\section{Discussion}

Definition of bipolar cell types. We have reconstructed 15 bipolar neurons from serial electron micrographs in order to establish a scheme for their classification. The reconstruction approach was favorable for this purpose because it provided information simultaneously about external morphology, cytoplasmic features, and synaptic circuitry. This approach also allowed us to compare neurons within a tiny region of a single retina, which meant that differences observed between cells could not be attributed to differences in retinal eccentricity (see Boycott and Wässle, 1974) or to interanimal variation. A "type" was defined when a cell exhibited a distinctive set of associations between morphology, cytology, and synaptic pattern. In all, there was evidence for one type of rod bipolar and seven types of cone bipolar cells. We believe these represent fundamental cell types in somewhat the same sense as neurons are "identified" in invertebrates.

Multiple examples were observed for two types, the rod bipolar and the cone bipolar, $\mathrm{CBb}_{1}$. All of the examples of each type were strikingly similar. Thus, the three rod bipolar cell axons were almost identical in form, diameter, and the depth in the inner plexiform layer where they dilated and began to make synapses. These axons were also remarkably constant in their absolute numbers of synaptic inputs $(35,39,42)$ and outputs $(27,28,32)$ and also in their ratios of specific types of presynaptic and postsynaptic processes (Tables II and III). The four reconstructed $\mathrm{CBb}_{1}$ axons also resembled each other remarkably in morphology, diameter, and the depth in the inner plexiform layer at which they formed synapses. Their arborizations, which were much more elaborate than those of the rod bipolar cell, could not be reconstructed in their entirety. Consequently, the absolute numbers of their inputs and outputs could not be determined; however, the ratios of specific types of contacts were remarkably consistent among the four axons. For example, inputs from reciprocal amacrine cells to $\mathrm{CBb}_{1}$ were $24,25,28$, and $30 \%$ of all inputs (Table II). Similarly, the outputs to amacrine cells were from 29 to $33 \%$ and outputs to ganglion cells were 19 to $26 \%$ of all outputs (Table III).

Wässle and colleagues (Wässle and Rieman, 1978; Wässle et al., 1978, 1981a, b) have reported in light microscope studies of 
TABLE V

Inputs to bipolar cells of sublamina $a^{a}$

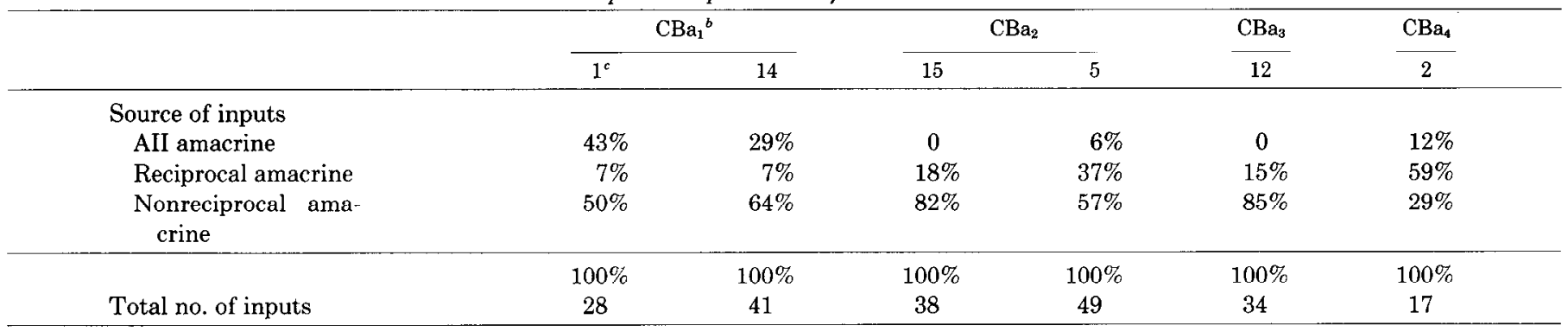

${ }^{a}$ Conventions for quantifying inputs are as in Table II.

${ }^{b}$ Cell type.

${ }^{c}$ Cell number.

TABLE VI

Outputs from bipolar cells in sublamina a

Conventions for quantifying outputs are as in Table III. Postsynaptic densities on AII cells were never as pronounced as for other cells, even though the AII profile was prominently positioned at the dyad.

\begin{tabular}{|c|c|c|c|c|c|c|}
\hline & \multicolumn{2}{|c|}{$\mathrm{CBa}_{1}{ }^{a}$} & \multicolumn{2}{|c|}{$\mathrm{CB} \mathbf{a}_{2}$} & \multirow{2}{*}{$\frac{\mathrm{CBd}_{3}}{12}$} & \multirow{2}{*}{$\frac{\mathrm{CBa}_{4}}{2}$} \\
\hline & $1^{b}$ & 14 & 15 & 5 & & \\
\hline \multicolumn{7}{|l|}{ To amacrine cells } \\
\hline AII amacrine & $18 \%$ & $29 \%$ & $4 \%$ & $4 \%$ & $3 \%$ & 0 \\
\hline Reciprocal amacrine & $1 \%$ & $2 \%$ & $10 \%$ & $21 \%$ & $5 \%$ & $23 \%$ \\
\hline Nonreciprocal amacrine & $15 \%$ & $8 \%$ & $19 \%$ & $23 \%$ & $10 \%$ & $18 \%$ \\
\hline Total amacrine & $34 \%$ & $39 \%$ & $33 \%$ & $48 \%$ & $18 \%$ & $41 \%$ \\
\hline \multicolumn{7}{|l|}{ To ganglion cells } \\
\hline Dark ganglion cell & $28 \%$ & $16 \%$ & $27 \%$ & $29 \%$ & $27 \%$ & $12 \%$ \\
\hline Pale ganglion cell & $13 \%$ & $23 \%$ & $19 \%$ & $2 \%$ & $34 \%$ & $2 \%$ \\
\hline Total ganglion cell & $41 \%$ & $39 \%$ & $46 \%$ & $21 \%$ & $61 \%$ & $14 \%$ \\
\hline Unidentified & $25 \%$ & $22 \%$ & $21 \%$ & $31 \%$ & $21 \%$ & $45 \%$ \\
\hline Total & $100 \%$ & $100 \%$ & $100 \%$ & $100 \%$ & $100 \%$ & $100 \%$ \\
\hline Total no. of outputs & 69 & 50 & 47 & 42 & 47 & 22 \\
\hline
\end{tabular}

${ }^{a}$ Cell type.

${ }^{b}$ Cell number.

horizontal and ganglion cells that cells of a particular type at a given locus in one retina are remarkably constant in soma size and dendritic field and that each type forms a regular array in the retinal mosaic. This appears to be true also for particular types of bipolar cell. Thus, $\mathrm{CBb}_{1}$ axons form a highly regular array with a nearest neighbor distance of $10 \pm 1 \mu \mathrm{m}$ (mean \pm SD; Freed and Sterling, 1983). One feature that appeared not to be constant was the exact depth of the soma in the inner nuclear layer of RB cells (Fig. 6). Conservation of form and synaptic connection but not of exact soma position is a hallmark of the neurons in invertebrate nervous systems that have been termed "identified" (Sterling, 1982).

Most of the types we have defined by serial reconstruction correspond to cells identified in previous studies, either by Golgi impregnation (Famiglietti, 1981; Kolb et al., 1981) or by intracellular recording and horseradish peroxidase injection (Kolb and Nelson, 1983; Nelson and Kolb, 1983). We review the correspondences in detail below for two reasons. First, they strengthen the definition of each cell type, especially where only one example was seen, and they establish that, for at least one small part of the mammalian nervous system, there is a correlation at the neuron level hetween form and function. Second, by knowing both the anatomical circuitry and, for some, the electrophysiology, it is possible to formulate specific hypotheses regarding why there might be such a diversity of cell types.

Correspondences between morphology, synaptic circuitry, and physiology. The cell identified as a rod bipolar corresponds precisely in morphology and cytology to the rod bipolar (RB) identified by previous authors (Boycott and Kolb, 1973; Kolb, 1979; Famiglietti, 1981; Kolb et al., 1981). The rod bipolar cell dendrite receives ribbon-related input from rods (e.g., Kolb, 1979). The reciprocal amacrine cell profiles, which provided $80 \%$ of the input to its axon terminal, are believed to derive from GABA-accumulating amacrine cells A13 and A17 (Kolb et al., 1981; Freed and Sterling, 1982; Pourcho and Goebel, 1983). The rod bipolar cell is hyperpolarizing to light (Nelson and Kolb, 1983) and is thought to be inhibitory because its hyperpolarization apparently causes depolarization of the AII amacrine to which it provides major input (Famiglietti and Kolb, 1975; Nelson, 1982).

The type of cone bipolar cell we call " $\mathrm{CBb}_{1}$," with a vertical, narrow field axon arborization in strata 3 to 5 , corresponds to "cb5" of Kolb et al. (1981) and "nb2" of Famiglietti (1981). Nelson and Kolb (1983) also have observed cb5, like our $\mathrm{CBb}_{1}$, to make extensive gap junctions with the AII amacrine cell. This type of bipolar cell is known to make "semi-invaginating basal" contacts at the cone pedicle and to possess a receptive field which is depolarizing to light in the center, with an antagonistic surround (Nelson and Kolb, 1983). The axon is believed from indirect evidence to be excitatory. Intracellular stimulation of depolarizing bipolar cells in fish has shown them to be excitatory to ganglion cells (Naka, 1977); thus, one expects a similar action from $\mathrm{CBb}_{1}$ in the cat, the only depolarizing bipolar cell known thus far to contact on-center ganglion cells. Also, $\mathrm{CBb}_{1}$ appears to be an excitatory link in the pathway 

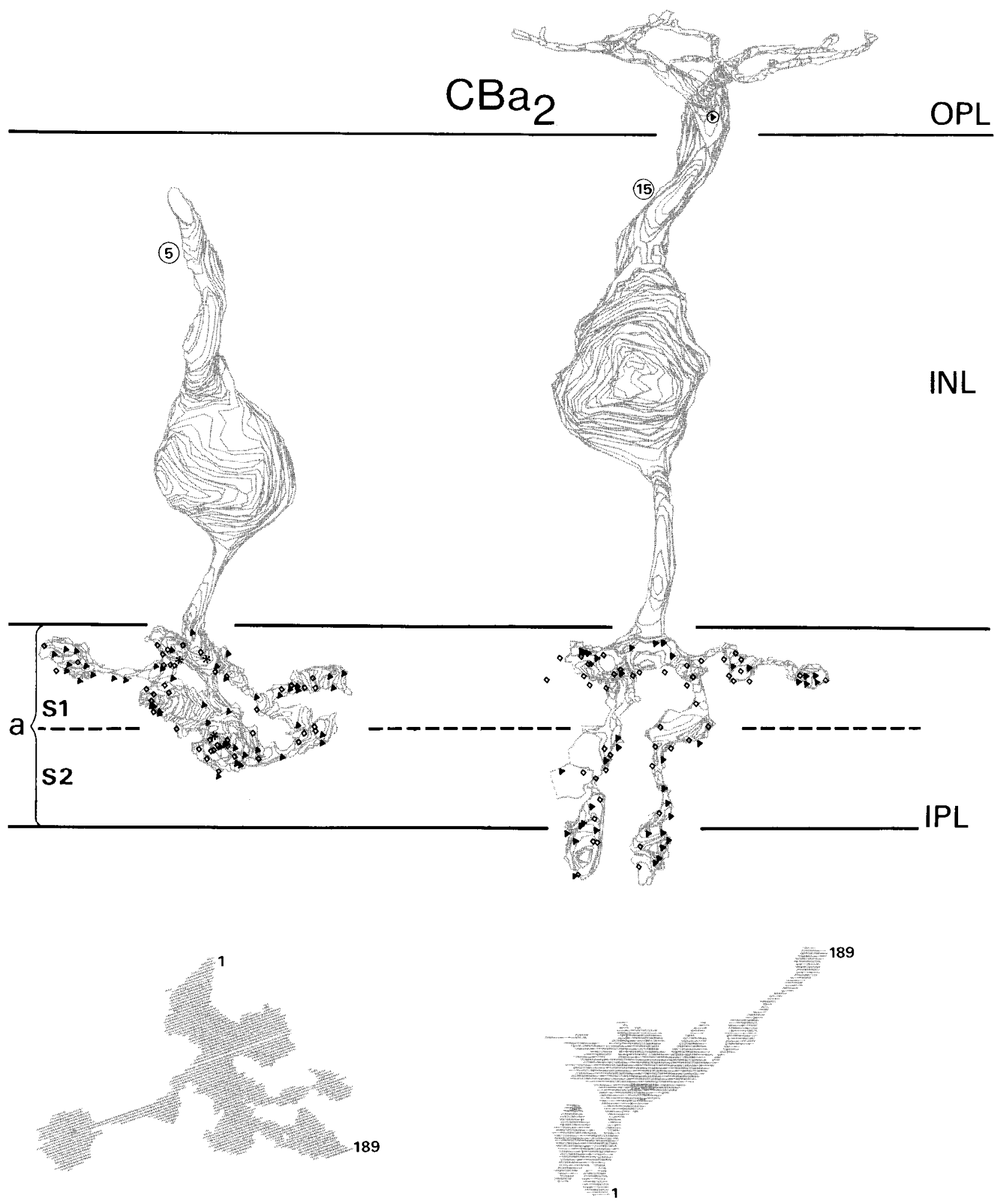

$10 \mu \mathrm{m}$

Figure 15. $\mathrm{CBa}_{2}$ reconstructions. Above, Cell 5 rotated $30^{\circ}$ and cell 15 rotated $180^{\circ}$ about the $\mathrm{Y}$ axis. Below, Both cells rotated $90^{\circ}$ about the $\mathrm{X}$ axis. Axon varicosities are prominent in all views. $\diamond$, outputs; $\boldsymbol{\Lambda}$, inputs; $*$, AII inputs; ( $)$, interplexiform cell input. $I N L$, inner nuclear layer; $I P L$, inner plexiform layer; $O P L$, outer plexiform layer.

from the depolarizing AII amacrine to the on ganglion cells (Figs. 8 and 20; see also Nelson and Kolb, 1983; Sterling, 1983).

The type of cone bipolar cell we call " $\mathrm{CBb}_{2}$," with an axon narrowly stratified in stratum 3 and upper stratum 4, corre- sponds to the wide-field "cb6" of Kolb et al. (1981) and probably to Famiglietti's (1981) "nb1." Although cb6 was illustrated by Kolb et al. (1981) as branching only within stratum 3, that study divided the inner plexiform layer into equal fifths (for 


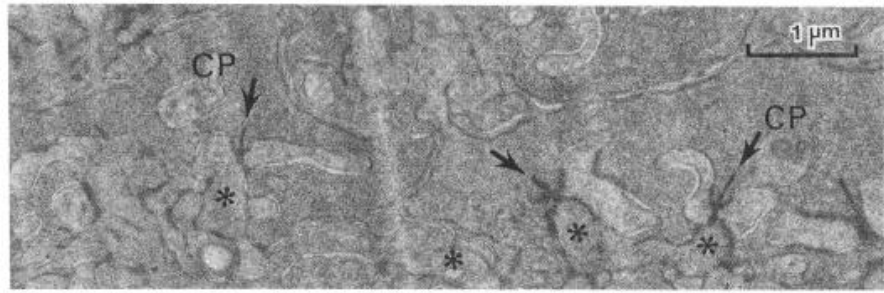

Figure 16. Electron micrograph of $\mathrm{CBa}_{2}$ dendrite (*), cell 15 , receiving multiple ribbon-related inputs (arrows) from two cone pedicles $(\mathrm{CP})$ in the outer plexiform layer.

technical reasons) so that $\mathrm{S} 3$ in their illustrations probably includes some of what is labeled $\mathrm{S} 4$ in ours. $\mathrm{CBb}_{2}$ may well have a wide axonal field because it is evident in the tangential view (Fig. 10, bottom) that certain branches extended beyond the region encompassed by our series. $\mathrm{Cb} 6$ of Kolb and Nelson (1983) is "semi-invaginating" with basal contacts from cones. The receptive field is hyperpolarizing without evidence of a surround.

The type of cone bipolar cell we call " $\mathrm{CBb}_{3}$ " has a stout axon arborizing mainly in stratum 4 and two sprigs arising from the axon trunk in stratum 1 that could not be followed. These sprigs might be the beginnings of a slender arborization headed for stratum 2. Were this so, $\mathrm{CBb}_{3}$ would correspond to "cb4" of Kolb et al. (1981), which has a bistratified axon arborization with thin branches in $\mathrm{S} 2$ and thick branches in $\mathrm{S} 4$, and to "wab" of Famiglietti (1981). The nature of its cone contacts and its response to light are unknown.

The type of cone bipolar cell we call " $\mathrm{CBa}_{1}$ " has a bushy axon arborizing in strata 1 and 2 . It corresponds most closely to type cb2 of Kolb et al. (1981) whose axon arborizes at the border of strata 1 and 2, and to either na1 or na2 of Famiglietti (1981). This type of bipolar cell receives flat contacts from cones (Fig. 13; Nelson and Kolb, 1983) and is hyperpolarizing (Nelson and Kolb, 1983).

The type of cone bipolar cell we call " $\mathrm{CBa}_{2}$," with a bushy axon arborization of scalloped, varicose processes, corresponds to the types "cb1" of Kolb et al. (1981) and na3 of Famiglietti (1981). We found this type to receive ribbon-related cone contacts (Fig. 16). This cell is presumed to be depolarizing to light, but no direct recordings have yet been made.
The type of cone bipolar cell we call " $\mathrm{CBa}_{3}$," with its smooth axon ramifying tangentially in strata 1 and 2 , resembles the "smooth, flat" cone bipolar described by Boycott and Kolb (1973). It does not correspond clearly, however, to any type in the recent schemes of Kolb et al. (1981) or Famiglietti (1981) because $\mathrm{CBa}_{3}$ ramifies in both strata 1 and 2 whereas cb3, the only possible candidate in the scheme of Kolb et al. (1981), is described as restricted to the border between these strata. The response of $\mathrm{CBa}_{3}$ to light has not yet been determined.

The type of cone bipolar cell we call " $\mathrm{CBa}_{4}$," with a thin axon ramifying above the border between sublaminae a and b, corresponds to type "cb3" of Kolb et al. (1981) and to type na/b of Famiglietti (1981). It has been shown to receive invaginating contacts from cones (Nelson and Kolb, 1983), but its responses to light have not been determined.

From these correspondences several points emerge. First, the categories of bipolar cell identified in the retina of one cat by reconstruction are also found in the retinas of other cats, which is part of the evidence that they are indeed specific cell types. Second, the size of the patch within which all of these types were found represents $0.06^{\circ} \times 0.6^{\circ}$ on the retina. This is less than the area covered by an $\alpha$ ganglion cell dendritic field and is in effect a "point" in the visual field. It follows that the visual image at every point on the cat retina must be analyzed by one type of rod bipolar cell and 8 to 10 types of cone bipolar cells, very much in the sense first suggested by Maturana et al. (1960). This is somewhat startling, since the cat is specialized for night vision and generally is considered rod dominated. One wonders what might be the function of so many cone bipolar types.

Possible functions for multiple types of cone bipolar cells. One function for cone bipolar cells might be to convey, separately or in specific combinations, cone signals of different spectral sensitivity. The only type of cone from which there are direct recordings has a peak sensitivity at $556 \mathrm{~nm}$ (Nelson, 1977), but behavioral studies and recordings from retina and lateral geniculate nucleus (Daw and Pearlman, 1969; Pearlman and Daw, 1970; Cleland and Levick, 1974) provide evidence for a second cone type with a peak sensitivity at $450 \mathrm{~nm}$. Recent ganglion cell recordings confirm these observations and provide evidence for a third type with peak sensitivity at $500 \mathrm{~nm}$ (Ringo and Wolbarsht, 1981; Zrenner and Weinrich, 1981). If information from three cone types regarding color is distributed to both the

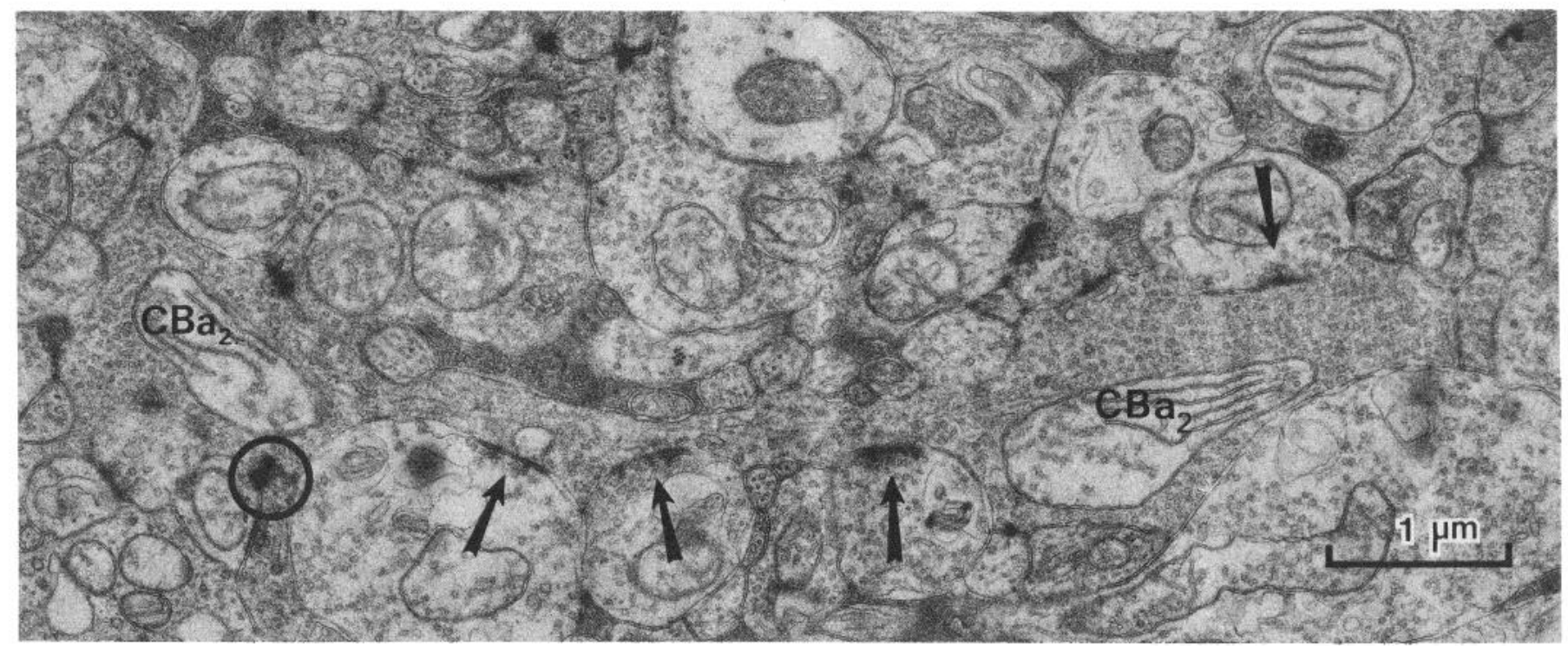

Figure 17. Electron micrograph of $\mathrm{CBa}_{2}$ axon in sublamina a, with unmistakably dark cytoplasm and scalloped varicosities. Arrows, amacrine cell inputs; circles, synaptic ribbon. 

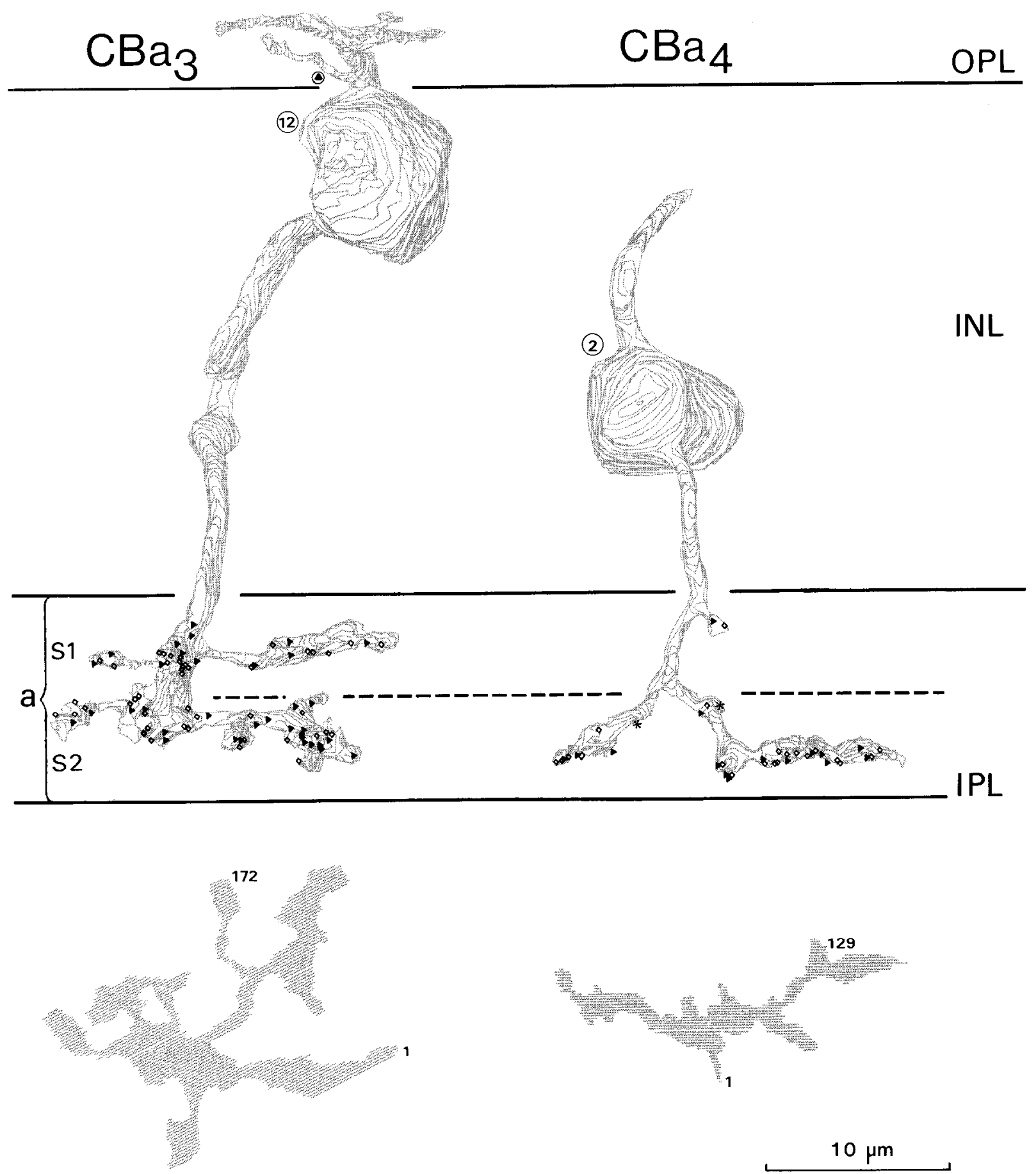

Figure 18. $\mathrm{CBa}_{3}$ and $\mathrm{CBa}_{4}$ reconstructions, with axons, below, rotated $90^{\circ}$ about the $\mathrm{X}$ axis. $\mathrm{CBa}_{3}$ 's smooth axon in $\mathrm{S} 1-2$ received no $\mathrm{AII}$ inputs $(*)$. The axon of $\mathrm{CBa}_{4}$ is smooth and delicate, branching in lower $\mathrm{S} 2 . \diamond$, outputs; $\Delta$, inputs; $\oplus$, interplexiform cell input. INL, inner nuclear layer; $I P L$, inner plexiform layer; $O P L$, outer plexiform layer.

on and the off sublaminae, it would not be surprising if many distinct types of cone bipolar cells were required. This would be especially true if, as is common, the information were conveyed in chromatically and spatially antagonistic forms (Daw, 1973). It is unknown whether the conc bipolar types described here are color coded.

Another important set of functions for the cone bipolar neurons is, oddly enough, to convey rod signals to ganglion cells via multiple pathways. Kolb (1979) reported that the rod bipolar cell provides no direct contacts to ganglion cells, although they had been seen in the rabbit retina (Raviola and Raviola,
1967). Our reconstructions reveal a few such contacts (Fig. 7, Table III; see also Freed and Sterling, 1983), but we agree that there is no evidence for a major direct pathway. The rod bipolar cell apparently has access to ganglion cells mainly via its multiple connections with the AII amacrine cell which in turn contacts at least six types of cone bipolar. The AII makes gap junction contacts in sublamina b with $\mathrm{CBb}_{1}$ and, to a lesser extent, with $\mathrm{CBb}_{2}$ and $\mathrm{CBb}_{3}$. The All lobular appendages make chemical contacts in sublamina a with $\mathrm{CBa}_{1}$ and, to a lesser extent, with $\mathrm{CBa}_{3}$ and $\mathrm{CBa}_{4}$. The rod signal is also transmitted laterally in the outer plexiform layer from rods to cones, ap- 


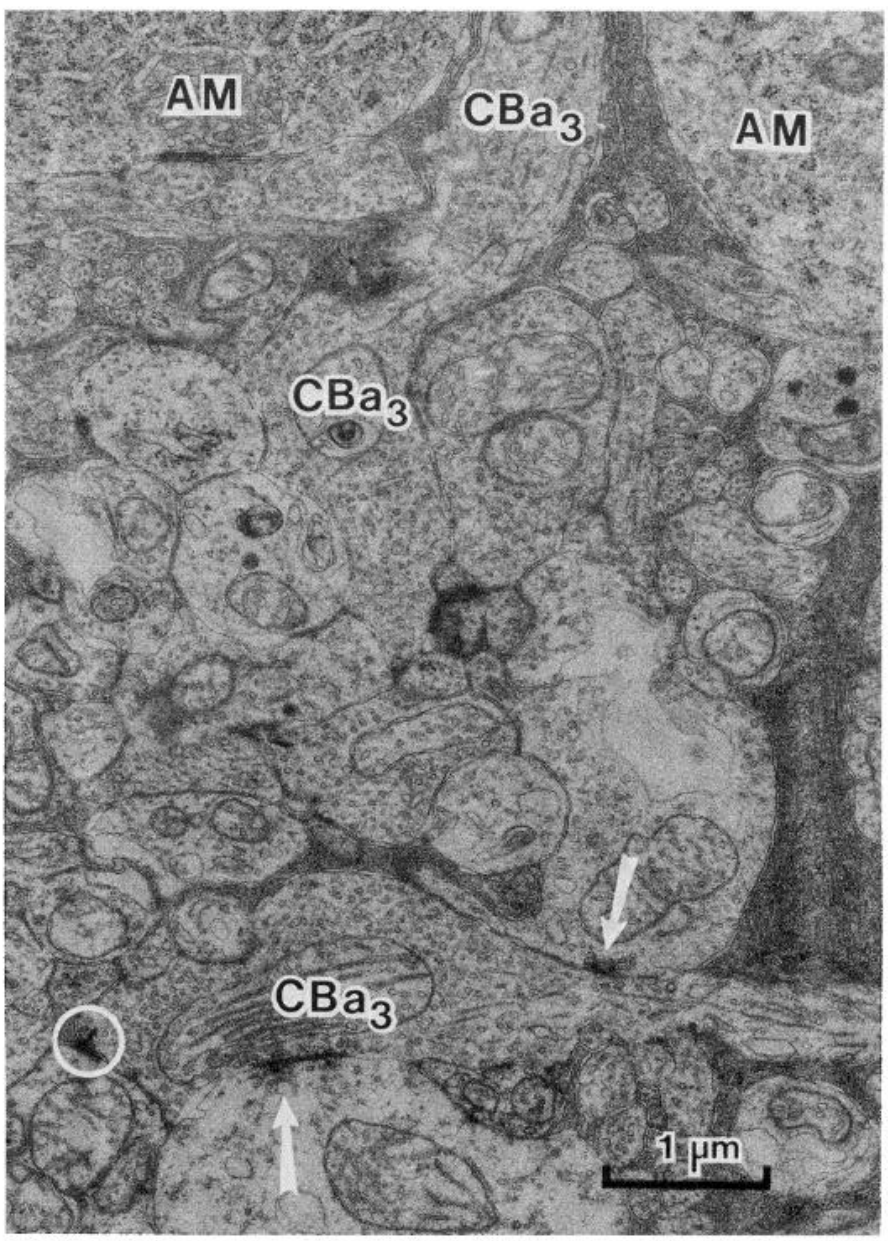

Figure 19. Electron micrograph of $\mathrm{CBa}_{3}$ axon. This type resembles $\mathrm{CBa}_{1}$ in single sections because its axon is pale and smooth in contour. Arrow, amacrine input; circle, synaptic ribbon; $A M$, amacrine cell soma. parently via gap junctions between the rod spherule and the basal processes of the cone pedicle (Kolb and Famiglietti, 1976; see also Kolb and Nelson, 1983). The cones may therefore transmit the rod signal indirectly to the dendrites of all types of cone bipolar cells. The cone bipolar cells may thus function in the dark as part of the rod system, as has been suggested before by Kolb and Famiglietti $(1974,1976)$ and Kolb and Nelson (1983). Specific roles for some of these pathways in dark adaptation have been proposed (Sterling, 1983).

It was believed that only one type of bipolar cell was required to generate the on-center or off-center response of a ganglion cell. The present observations, however, suggest that two or more types of bipolar cells may be involved. We observed that two types of cone bipolar cells in each sublamina form what appear to be complementary pairs, each pair converging on a specific type of $\beta(\mathrm{X})$ ganglion cell. In sublamina $\mathrm{b}, \mathrm{CBb}_{1}$ is depolarizing and probably excitatory whereas $\mathrm{CBb}_{2}$ is hyperpolarizing and possibly inhibitory. Both provide multiple contacts to the on- $\beta$ ganglion cell. Correspondingly, in sublamina $\mathrm{a}, \mathrm{CBa}_{1}$ is hyperpolarizing and probably excitatory whereas $\mathrm{CBa}_{2}$ is depolarizing and possibly inhibitory. Both provide multiple contacts to the off- $\beta$ ganglion cell. We have suggested that the $\beta$ cell receptive field might be generated by simultaneous excitation from one member of each bipolar pair and disinhibition from the other (McGuire et al., 1982). Thus, to generate the photopic receptive field of an on- or off-center $\beta$ ganglion cell may require not one, but two types of cone bipolar cells, and in this manner a specific function for four types might be accounted for. Such connections with $\beta$ cells are described in more detail in a subsequent paper (B. A. McGuire, J. K. Stevens, and P. Sterling, manuscript in preparation).

\section{References}

Boycott, B. B., and H. Kolb (1973) The connections between bipolar cells and photoreceptors in the retina of the domestic cat. J. Comp. Neurol. 148: 91-114.

Boycott, B. B., and H. Wässle (1974) The morphological types of ganglion cells of the domestic cat's retina. J. Physiol. (Lond.) 240: $397-419$.

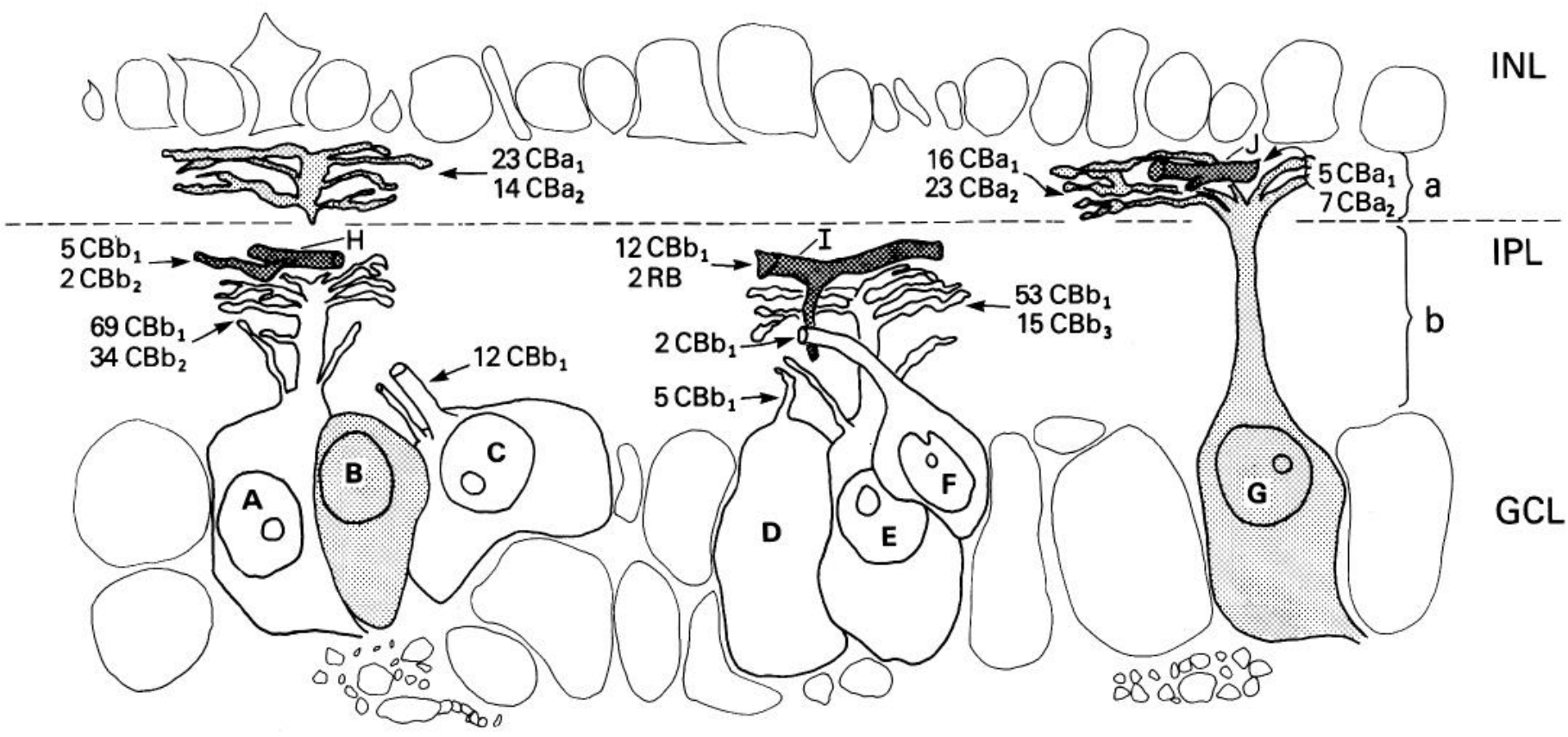

$10 \mu \mathrm{m}$

Figure 20. Schematic drawing of seven ganglion cells and three isolated dendrites that received multiple bipolar inputs. Cells: $A, D$, and $E$, on$\beta$ cells; $B$ and $G$, off- $\beta$ cells; $C$, possible $\epsilon$ cell; $F$, small ganglion cell. Dendrites: $H$, possible on- $\alpha$ cell; $J$, probable off- $\alpha$ cell dendrite. Dendrite $I$, possibly on- $\alpha$, although it is less regular in contour than $H$ or $J$, received both cone and rod bipolar inputs. See the text for details. $G C L$; ganglion cell layer; $I N L$, inner nuclear layer; $I P L$, inner plexiform layer. 
Cleland, B. G., and W. R. Levick (1974) Properties of rarely encountered types of ganglion cells in the cat's retina. J. Physiol. (Lond.) 240: 457-492.

Daw, N. W. (1973) Neurophysiology of color vision. Physiol. Rev. 53. $571-611$

Daw, N. W., and A. L. Pearlman (1969) Cat colour vision: One cone process or several? J. Physiol. (Lond.) 201: 745-764.

Dowling, J. E., and B. B. Boycott (1966) Organization of the primate retina: Electron microscopy. Proc. R. Soc. Lond. (Biol.) 166: 80-111.

Famiglietti, E. V., Jr. (1981) Functional architecture of cone bipolar cells in mammalian retina. Vision Res. 21: 1559-1564.

Famiglietti, E. V., Jr., and H. Kolb (1975) A bistratified amacrine cell and synaptic circuitry in the inner plexiform layer of the retina. Brain Res. 84: 293-300.

Famiglietti, E. V., Jr., and H. Kolb (1976) Structural basis for ON- and OFF-center responses in retinal ganglion cells. Science 194: 193-195.

Freed, M. A., and P. Sterling (1982) Amacrines reciprocal to the rod bipolar in cat retina are GABA-accumulating. Soc. Neurosci. Abstr. 8: 46.

Freed, M. A., and P. Sterling (1983) Spatial distribution of input from depolarizing cone bipolars to dendritic tree of on-center alpha ganglion cell. Soc. Neurosci. Abstr. 9: 806.

Holmgren-Taylor, I. (1982) Electron microscopical observations on the indoleamine-accumulating neurons and their synaptic connections in the retina of the cat. J. Comp. Neurol. 208: 144-156.

Kaneko, A. (1970) Physiological and morphological identification of horizontal, bipolar and amacrine cells in goldfish retina. J. Physiol. (Lond.) 207: 623-633.

Kidd, M. (1962) Electron microscopy of the inner plexiform layer of the retina in the cat and pigeon. J. Anat. 96: 179-188.

Kolb, H. (1979) The inner plexiform layer in the retina of the cat: Electron microscope observations. J. Neurocytol. 8: 295-329.

Kolb, H., and E. V. Famiglietti, Jr. (1974) Rod and cone pathways in the inner plexiform layer of cat retina. Science 186: 47-49.

Kolb, H., and E. V. Famiglietti, Jr. (1976) Rod and cone pathways in the retina of the cat. Invest. Ophthalmol. 15: 935-946.

Kolb, H., and R. Nelson (1983) Rod pathways in the retina of the cat. Vision Res. 23: 301-312.

Kolb, H., and R. W. West (1977) Synaptic connections of the interplexiform cells in the retina of the cat. J. Neurocytol. 6: 155-170.

Kolb, H., R. Nelson, and A. Mariani (1981) Amacrine cells, bipolar ceils and ganglion cells of the cat retina: A Golgi study. Vision Res. 21: $1081-1114$.

Maturana, H. R., J. H. Lettvin, W. S. McCullough, and W. H. Pitts (1960) Anatomy and physiology of vision in the frog (Rana pipiens). J. Gen. Physiol. 43: 129-176.

McGuire, B. A., J. K. Stevens, and P. Sterling (1982) "Push-pull" microcircuitry of the beta (X) ganglion cell in light adaptation. Invest. Ophthalmol. Vis. Sci. Suppl. 22: 3.

Miller, R. F., R. F. Dacheux, and T. E. Frumkes (1977) Amacrine cells in Necturus retina: Evidence for independent $\gamma$-aminobutyric acidand glycine-releasing neurons. Science 198: 748-750.

Naka, K. -I. (1977) Functional organization of catfish retina. J. Neurophysiol. 40: 26-43.

Nakamura, Y., B. McGuire, and P. Sterling (1978) Selective uptake of $\gamma-\left[{ }^{3} \mathrm{H}\right]$-aminobutyric acid and $\left[{ }^{3} \mathrm{H}\right]$ glycine by neurons of the amacrine layer of cat retina. Soc. Neurosci. Abstr. 4: 2046.

Nakamura, Y., B. McGuire, and P. Sterling (1980) Interplexiform cell in cat retina: Identification by uptake of $\gamma-\left[{ }^{3} \mathrm{H}\right]$-aminobutyric acid and serial reconstruction. Proc. Nat.l. Acad. Sci. U. S. A. 77: 658 661.
Nelson, R. (1977) Cat cones have rod input: A comparison of the response properties of cones and horizontal cell bodies in the retina of the cat. J. Comp. Neurol. 172: 109-136.

Nelson, R. (1982) AII amacrine cells quicken time course of rod signals in the cat retina. J. Neurophysiol. 47: 928-947.

Nelson, R., and H. Kolb (1983) Synaptic patterns and response properties of bipolar and ganglion cells in the cat retina. Vision Res. 23 1183-1195.

Nelson, R., E. V. Famiglietti, Jr., and H. Kolb (1978) Intracellular staining reveals different levels of stratification for $\mathrm{ON}$ - and OFF. center ganglion cells in cat retina. J. Neurophysiol. 2: 472-483.

Pearlman, A., and N. Daw (1970) Opponent color cells in the cat lateral geniculate nucleus. Science 167: 84-86.

Pourcho, R. (1980) Uptake of $\left[{ }^{3} \mathrm{H}\right]$ glycine and $\left[{ }^{3} \mathrm{H}\right] \mathrm{GABA}$ by amacrine cells in the cat retina. Brain Res. 198:333-346.

Pourcho, R., and D. J. Goebel (1983) Neuronal subpopulations in cat retina which accumulate the GABA agonist, $\left({ }^{3} \mathrm{H}\right)$ muscimol: A combined Golgi and autoradiographic study. J. Comp. Neurol. 219: 25 35

Ramón y Cajal, S. (1972) The Structure of the Retina, S. A. Thorpe and M. Glickstein, eds. and transl., Charles C Thomas, Springfield, IL.

Raviola, G., and E. Raviola (1967) Light and electron microscopic observations on the inner plexiform layer of the rabbit retina. Am J. Anat. 120: 403-426.

Ringo, J., and H. G. Wolbarsht (1981) Color coding in cat retinal ganglion cell receptive fields. Invest. Ophthalmol. Vis. Sci. Suppl. 20: 185.

Sterling, P. (1982) Identified neurons in the cat retina. In Changing Concepts of the Nervous System, Proceedings of the First Institute in Neurological Sciences Symposium in Neurobiology, A. R. Morrison and P. L. Strick, eds., pp. 281-293, Academic Press, Inc., New York.

Sterling, P. (1983) Microcircuitry of the cat retina. Annu. Rev. Neurosci. $6: 149-185$

Stevens, J. K., T. L. Davis, N. Friedman, and P. Sterling (1980a) A systematic approach to reconstructing microcircuitry by electron microscopy of serial sections. Brain Res. Rev. 2: 265-293.

Stevens, J. K., B. A. McGuire, and P. Sterling (1980b) Toward a functional architecture of the retina: Serial reconstruction of adjacent ganglion cells. Science 207: 317-319.

Wässle, H., and H. J. Riemann (1978) The mosaic of nerve cells in the mammalian retina. Proc. R. Soc. Lond. (Biol.) 200: 441-461.

Wässle, H., L. Peichl, and B. B. Boycott (1978) Topography of horizontal cells in the retina of the domestic cat. Proc. R. Soc. Lond. (Biol.) 203: 269-291.

Wässle, H., L. Peichl, and B. B. Boycott (1981a) Morphology and topography of on- and off-alpha cells in the cat retina. Proc. R. Soc. Lond. (Biol.) 212: 157-175.

Wässle, H., B. B. Boycott, and R. B. Illing (1981b) Morphology and mosaic of on- and off-beta cells in the cat retina and some functional considerations. Proc. R. Soc. Lond. (Biol.) 212: 177-195.

West, R. W. (1978) Bipolar and horizontal cells of the gray squirrel retina: Golgi morphology and receptor connections. Vision Res. 18. 129-136.

Witkovsky, P., and W. K. Stell (1973) Retinal structure in the smooth dogfish, Mustelus canis: Light microscopy of bipolar cells. J. Comp. Neurol. 148: 47-60.

Wyatt, H. J., and N. W. Daw (1976) Specific effects of neurotransmitter antagonists on ganglion cells in rabbit retina. Science 191: 204-205.

Zrenner, E., and J. Weinrich (1981) Chromatic signals in the retina of cat and monkey. Invest. Ophthalmol. Vis. Sci. Suppl. 20: 185. 